\title{
Quantitative human health risk assessment along the lifecycle of nano-scale copper- based wood preservatives
}

Hristozov, Danail; Pizzol, Lisa; Basei, Gianpietro; Zabeo, Alex; Mackevica, Aiga; Hansen, Steffen Foss; Gosens, Ilse; Cassee, Flemming R.; de Jong, Wim; Koivisto, Antti Joonas

Total number of authors:

19

Published in:

Nanotoxicology

Link to article, DOI:

10.1080/17435390.2018.1472314

Publication date:

2018

Document Version

Peer reviewed version

Link back to DTU Orbit

Citation (APA):

Hristozov, D., Pizzol, L., Basei, G., Zabeo, A., Mackevica, A., Hansen, S. F., Gosens, I., Cassee, F. R., de Jong, W., Koivisto, A. J., Neubauer, N., Sanchez Jimenez, A., Semenzin, E., Subramanian, V., Fransman, W., Jensen, K. A., Wohlleben, W., Stone, V., \& Marcomini, A. (2018). Quantitative human health risk assessment along the lifecycle of nano-scale copper-based wood preservatives. Nanotoxicology, 12(7), 747-765.

https://doi.org/10.1080/17435390.2018.1472314

\section{General rights}

Copyright and moral rights for the publications made accessible in the public portal are retained by the authors and/or other copyright owners and it is a condition of accessing publications that users recognise and abide by the legal requirements associated with these rights.

- Users may download and print one copy of any publication from the public portal for the purpose of private study or research.

- You may not further distribute the material or use it for any profit-making activity or commercial gain

- You may freely distribute the URL identifying the publication in the public portal 


\section{Quantitative human health risk assessment along the lifecycle of nano-scale 2 copper-based wood preservatives}

4 Hristozov, Danail ${ }^{1,2}$; Pizzol, Lisa ${ }^{1,2}$; Zabeo, Alex ${ }^{1,2}$; Basei, Gianpietro ${ }^{1}$; Mackevica, Aiga ${ }^{3}$; Hansen, Steffen

5 Foss ${ }^{3}$; Gosens, Ilse ${ }^{4}$; Cassee, Flemming R. ${ }^{4,10}$; de Jong, Wim ${ }^{4}$; Koivisto, Joonas ${ }^{5}$; Neubauer, Nicole ${ }^{6}$;

6 Sanchez Jimenez, Araceli ${ }^{7}$; Semenzin, Elena ${ }^{1}$; Subramanian, Vrishali ${ }^{1}$; Fransman, Wouter ${ }^{8}$; Jensen, Keld

7 Alstrup ${ }^{5}$; Wohlleben, Wendel $^{6}$; Stone, Vicki ${ }^{9}$; Marcomini, Antonio ${ }^{1}$

8

9 1. Department of Environmental Sciences, Informatics and Statistics, University Ca' Foscari, Venice, 10 Italy

11 2. Greendecision Srl., Venice, Italy

12 3. Department of Environmental Engineering, Technical University of Denmark, Kongens Lyngby, 13 Denmark

14 4. National Institute for Public Health and the Environment, Bilthoven, Netherlands.

15 5. National Research Centre for the Working Environment, Copenhagen, Denmark.

16 6. BASF SE, Ludwigshafen, Germany

17 7. Institute of Occupational Medicine, Edinburgh, United Kingdom

18 8. Netherlands Organisation for applied scientific research TNO, Zeist, Netherlands

19 9. Heriot-Watt University, School of Life Sciences, Nanosafety Research Group, Edinburgh, United 20 Kingdom

21 10. Institute of Risk Assessment Studies, Utrecht University, Netherlands.

\section{Abstract}

23 The use of nano-scale copper oxide $(\mathrm{CuO})$ and basic copper carbonate $\left(\mathrm{Cu}_{2}(\mathrm{OH})_{2} \mathrm{CO}_{3}\right)$ in both ionic and 24 micronized wood preservatives has raised concerns about the potential of these substances to cause 25 adverse humans health effects. To address these concerns, we performed quantitative (probabilistic) 26 human health risk assessment (HHRA) along the lifecycles of these chemicals used in antifungal wood 27 coatings and impregnations. The results from the risk analysis revealed inhalation risks from $\mathrm{CuO}$ in 28 exposure scenarios involving workers handling dry powders and performing sanding operations as well 29 as potential ingestion risks for children exposed to nano $\mathrm{Cu}_{2}(\mathrm{OH})_{2} \mathrm{CO}_{3}$ in a scenario involving the hand-to30 mouth transfer of impregnated wood. There are, however, substantial uncertainties in these results, so 31 some of the identified risks may stem from the safety margin of extrapolation to fill data gaps and may 32 be resolved by additional testing. 
The adopted stochastic approach was preferred to deterministic analyses in the sense that it can communicate the contribution of each source of uncertainty and therefore can help in developing strategies to reduce it. Our analysis demonstrated that the main source of uncertainty is the extrapolation from short to long term exposure, which was necessary due to the lack of (sub)chronic in vivo studies with $\mathrm{CuO}$ and $\mathrm{Cu}_{2}(\mathrm{OH})_{2} \mathrm{CO}_{3}$. Considerable uncertainties also stemmed from the use of default inter- and intra-species extrapolation factors. The proposed approach is currently unable to assess the uncertainties resulting from using data from studies involving different nanoforms of the same substance, which makes it only suitable to apply on a case-by-case basis.

Keywords: Probabilistic human health risk assessment, Engineered nanomaterials, Copper oxide; Copper carbonate; Occupational and consumer exposure scenarios, Benchmark dose, SUN Decision Support System

\section{Introduction}

Preservation treatment is essential for increasing the service life of timber by imparting it with fungicidal and insecticidal properties. Copper-based preservatives have been widely used to treat softwood intended for commercial use due to their high performance and relatively low mammalian toxicity (Freeman and McIntyre 2008, Lebow and Foster 2005).

In response to the identified health risks from the chromated copper arsenate (CCA), chemical formulations without arsenic and chromium using ionic copper as the primary insecticide and fungicide were developed in the late 80 s. Some key examples include the alkaline copper quaternary (ACQ), copper azole, and copper xyligen. Since then ionic copper formulations have become the dominant treatment for outdoor residential applications such as decking, gardening, fencing, and playground equipment in Europe. However, while they were effective in timber preservation, increased leaching of copper ions into the surrounding environment resulted in the degradation of metal fasteners and subsequent structural failure.

Micronized copper has been promoted as an alternative to ionic copper that can address these corrosion and treatment life issues (Freeman and McIntyre 2008). It has limited market penetration in the EU due to a lack of regulatory approval, but over $75 \%$ of the residential lumber produced in the USA 60 is nowadays treated with micronized copper (Freeman and Mcintyre 2013) produced by mechanical 61 grinding of compounds such as basic copper carbonate $\left(\mathrm{Cu}_{2}(\mathrm{OH})_{2} \mathrm{CO}_{3}\right)$ or copper oxide $(\mathrm{CuO})$ with 
dispersing agents in a carrier solution (Freeman and McIntyre 2008). The size of the resulting particles ranges from 1 to $25000 \mathrm{~nm}$, with typically $90 \%$ of the particles below the size of $1000 \mathrm{~nm}$ (Freeman and

64 McIntyre 2008). Leaching is significantly controlled in micronized wood treatments as compared to ionic wood treatments, and less than $5 \%$ of it was in particulate form (Platten et al. 2014). While a proportion of micronized copper formulations are nano-sized (Freeman and Mclntyre 2008), the potential 67 additional advantage offered by copper formulations within the nano-size range are even more 68 substantially being considered (Clausen 2007, Evans et al. 2008, Kartal et al. 2009). Clausen (2007) 69 argues that dispersion stability coupled with controlled particle size in nano-sized wood preservative 70 formulations may greatly improve preservative penetration, treatability of refractory wood species and 71 stability of finishes and coatings for above ground applications. Accordingly, nanoparticles of CuO and $72 \mathrm{Cu}_{2}(\mathrm{OH})_{2} \mathrm{CO}_{3}$ have been increasingly considered for micronized wood treatment formulations (Clausen 73 2007, Evans et al. 2008, Kartal et al. 2009).

The increased use of nano-scale $\mathrm{CuO}$ and $\mathrm{Cu}_{2}(\mathrm{OH})_{2} \mathrm{CO}_{3}$ as timber preservatives has raised concerns about the potential of these substances to cause undesirable human health effects. In spite of the fact that ionic copper formulations are currently thoroughly reviewed in Europe for their human and environmental risks under the Biocidal Products regulation (Regulation (EU) No 528/2012), there are only few studies that attempted to assess their risks (US EPA 2003, Civardi et al. 2015). Therefore, we performed a quantitative human health risk assessment ( $\mathrm{HHRA}$ ) of nano-scale $\mathrm{CuO}$ and $\mathrm{Cu}_{2}(\mathrm{OH})_{2} \mathrm{CO}_{3}$ along the lifecycles of antimicrobial/antifungal coatings and impregnations. This is the first quantitative estimation of the risks from these products from lifecycle perspective.

We applied the HHRA framework for regular chemicals as it has been considered by the European Scientific Committee on Emerging and Newly Identified Health Risks (SCENIHR) applicable to nanomaterials (SCENIHR 2009). This approach consists of hazard identification, dose-response assessment, exposure assessment and risk characterization steps (Van Leeuwen and Vermeire 2007). We applied it as a probabilistic methodology designed to quantitatively estimate and communicate the uncertainties in each of these steps in order to demonstrate how they influence the final results (Tsang et al. 2017, Pang et al. 2017). Then we implemented this methodology as a software module in the webbased EU FP7 SUN project's Decision Support System (SUNDS), which enabled it to estimate occupational, consumer and public health risks from manufactured nanomaterials along the lifecycles of nano-enabled products. 
This paper demonstrates the SUNDS HHRA module with dose-response data from in vivo experiments specifically designed to measure the subacute effects following inhalation and oral uptake of nanoscale

$94 \mathrm{CuO}$ and $\mathrm{Cu}_{2}(\mathrm{OH})_{2} \mathrm{CO}_{3}$. The dose-response relationships were compared to external human exposure concentrations estimated for 13 relevant exposure scenarios (ES), which were formulated based on release data and contextual information on a CuO-based acrylic coating and a $\mathrm{Cu}_{2}(\mathrm{OH})_{2} \mathrm{CO}_{3}$-containing

97 impregnation.

\section{Methods}

\subsection{Case study products}

\subsubsection{CuO used in an antimicrobial/antifungal wood protective coating}

101 $\mathrm{CuO}$ pristine nanoparticles were obtained as a black powder from the company PlasmaChem $\mathrm{GmbH}$, Berlin, Germany. They were synthesized by thermal decomposition of an inorganic precursor in solid phase. The synthesized and dry-milled $\mathrm{Cu}_{2}(\mathrm{OH})_{2} \mathrm{CO}_{3}$ precursor was decomposed at approximately $350^{\circ} \mathrm{C}$ for several hours. The derived crystalline powder had a TEM particle size of 15-20 nm, a BrunauerEmmett-Teller (BET) specific surface area of $47 \mathrm{~m}^{2} / \mathrm{g}$ and a bulk material density of $6.3 \mathrm{~g} / \mathrm{cm}^{3}$ according to the supplier. To check consistency with these data and complement them, we performed detailed physicochemical characterisation of size (distribution), shape, crystallite phases, dispersability, agglomeration/aggregation, stability, surface area and chemistry, chemical composition and impurities. The adopted methods and the obtained results are described in detail in the Supporting Information (Table SI_1). They are not detailed in this section because the focus of this paper is on the risk characterisation calculations, which are based on measured hazard and exposure and are therefore not directly dependent on the physicochemical properties.

The $\mathrm{CuO}$ nanopowder was dispersed in a solution by mixing according to an established BASF protocol

114 (Tiarks et al. 2003). Specifically, we added it to a high-gloss acrylic wood coating, where the anticipated 115 antimicrobial activity of the $\mathrm{CuO}$ would provide the additional functionalities of sealing the wood and 116 serving decorative purposes. The wood coating liquid was then applied either by spraying or brushing 117 onto the surface of blocks of pine wood with dimensions of $2.5 \times 2.5 \times 1 \mathrm{~cm}(\mathrm{n}=70)$. Some of the blocks 118 were coated entirely with a $\mathrm{CuO}$-free $\left(\mathrm{TiO}_{2}\right)$ coating to serve as a negative control. The rest of them were 119 coated on one side with the $\mathrm{TiO}_{2} / \mathrm{CuO}$ coating on a chemically inert substrate (Teflon or Poly Ethylene) 
121 ES (cf. 2.2.2). The coatings were thoroughly characterised, and the results are reported in Pantano et al.

122 (2018) and in the Supporting Information (Tables SI_2 and SI_3).

123

124

125

126

127

128

129

130

131

132

133

134

\subsection{2 $\mathrm{Cu}_{2}(\mathrm{OH})_{2} \mathrm{CO}_{3}$ used in an antimicrobial/antifungal wood protective impregnation}

Dispersed $\mathrm{Cu}_{2}(\mathrm{OH})_{2} \mathrm{CO}_{3}$ nanoparticles were obtained from PlasmaChem $\mathrm{GmbH}$, Berlin, Germany. In the process of formulating an impregnation solution, the basic copper carbonate was wet milled until it reached nano-sized particles. The $\mathrm{Cu}_{2}(\mathrm{OH})_{2} \mathrm{CO}_{3}$ was then combined with water, stabilisers and cobiocides to make the stock solution. Small wood blocks were then immersed/soaked in this impregnation dispersion. This was adequate for research purposes, but on industrial scale pressure impregnation is typically carried out in steel cylinders or retorts. The wood is loaded on special tram cars and moved into the retort, which is then closed, evacuated and subsequently filled with preservative solution. Then pressure forces the preservative into the wood until the desired amount is absorbed.

The results of the performed detailed physicochemical characterisation of the micronised $\mathrm{Cu}_{2}(\mathrm{OH})_{2} \mathrm{CO}_{3}$ suspention and the impregnated wood are reported in Pantano et al. (2018) and are summarised in the Suplemental Information (Tables SI_2 and SI_3).

\subsection{Risk assessment by means of SUNDS}

SUNDS is a web-based software system that has been designed to estimate occupational, consumer, public health and environmental risks from nanomaterials in real industrial products along their lifecycles. In situations where the risks are not controlled SUNDS proposes suitable Risk Management Measures, including information about their costs versus the benefits of the technologies. The SUNDS framework was previously described (Subramanian et al. 2016), where the computational risk assessment approach illustrated in this paper is part of the SUNDS Tier 2 and is described in more detail in (Pizzol et al.). This probabilistic HHRA module is designed to quantitatively estimate and communicate the uncertainties in each step of the risk analysis. The system can simultaneously assess risks in different lifecycle stages, targets, activities and routes of exposure based on in vivo toxicity data and ES. It is schematically depicted in Figure 1.

For each ES, based on a combination of the exposure assessment (estimation of external concentration) and hazard assessment (estimation of human effect threshold dose) the system produces a discrete value or a probability distribution of risk and the associated uncertainty. To do this, SUNDS uses exposure measurements, or if such are not available exposure can be estimated by means of models 
(e.g. NanoSafer, Ingestion Exposure Tool) that are either integrated in the system or interact with it externally. To assess a human effect threshold SUNDS can use in vivo raw data to perform doseresponse analysis by means of a dedicated model and then to correct the obtained Point of Departure

153 (PoD) (i.e. Benchmark Dose (BMD)) and extrapolate it to a human dose (HD) by means of the APROBA 154 tool, which is integrated in the system. In some cases, the PoD (e.g. BMD or No-observed Adverse Effect 155 Level (NOAEL)) is available from the published literature and therefore can be directly imported in the 156 system instead of analysing raw data. This is the case of this risk assessment, where the dose-response 157 analysis involved PoD estimated in other studies, which were only corrected and extrapolated to HD by 158 means of SUNDS/APROBA as it is described in 2.2.2.

Insert Figure 1 here

The following sections 2.2.1-2.2.3 describe how the SUNDS HHRA module was applied for exposure and hazard assessment of the case-studies presented in 2.1 to assess occupational and consumer risks along their lifecycles and to communicate the associated uncertainties.

\subsubsection{Exposure assessment}

\subsubsection{Formulation of exposure scenarios}

165 To gather the knowledge and expertise needed to formulate realistic workplace and consumer ES we performed a literature review, organised a dedicated workshop and obtained additional contextual information from the industrial companies BASF and Koppers Inc.

Specifically, published literature from 2000 to 2016 was searched for relevant release and exposure assessment studies. To do this we queried the Web of Science database with combinations of the following keywords: nano, copper oxide, copper carbonate, micronized copper, $\mathrm{CuO}, \mathrm{CuCO}_{3}$,

172 consumer, use. The literature search resulted in a small number of documents, which were carefully 173 analysed. In addition, mapping of release hot spots along the lifecycles of the investigated products was 174 performed as part of the SUN project (Steinfeldt 2017). We used these results as a basis to design the 175 exposure assessment expert workshop.

176 The workshop took place on 22 January 2016 in Venice and was attended by 22 academic and industrial 177 experts in human exposure assessment and copper-based timber preservatives from EU, US and Russia. 178 The discussions resulted in generic ES, which were then further elaborated with information obtained 
from the literature and from the industrial companies BASF and Koppers Inc. The formulated ES covered the entire lifecycles (i.e. synthesis, formulation, use, end-of-life) of the investigated products and are listed in Table 2. In cases when estimations of exposure were not available in the literature, such were derived in the SUN project by means of the experimental and modelling methods described in 2.2.2.

\subsubsection{Estimation of exposure}

The following experimental and modelling activities were performed with our case study products (cf. 2.1) in order to derive exposure estimations for each of the formulated ES for performing risk assessment by means of SUNDS. The numbering of the different ES corresponds to Table 2.

\section{ES 1 and 6 involving laboratory production, handling and packing of nanoscale $\mathrm{CuO}$ and $\mathrm{Cu}_{2}(\mathrm{OH})_{2} \mathrm{CO}_{3}$ powders}

$\mathrm{CuO}$ and $\mathrm{Cu}_{2}(\mathrm{OH})_{2} \mathrm{CO}_{3}$ nanoscale powders are produced using sol gel synthesis. The sol gel synthesis and packing were performed in a fume hood where the bags were canned, and the cans were subsequently moved to a storage room. Occupational exposure measurements were performed, which resulted in breathing zone and far field respirable mass concentrations below the minimum detection limits of 161 and $26 \mu \mathrm{g} \mathrm{m}^{-3}$, respectively (Fonseca et al.). The surface wipe samples analysed with a Scanning Electron Microscope (SEM) did not reveal any CuO particles (Fonseca et al.). Therefore, based on these results we concluded that the exposure levels for ES 1 and 6 are negligible.

\section{ES 2 and 7 involving pouring nanoscale CuO powders in the wood coating stock solutions}

The nanoscale $\mathrm{CuO}$ pouring to the liquid matrix was not measured. The exposure levels were estimated by means of a one-box model (Hewett and Ganser 2017). Laboratory scale powder mixing was assumed to be performed without using any emission controls (i.e. worst-case scenario). The parameters used for modelling of manufacturing $100 \mathrm{~L} \mathrm{CuO} \mathrm{preservative} \mathrm{are} \mathrm{the} \mathrm{following:} \mathrm{Dustiness} \mathrm{index}=104 \mathrm{mg} / \mathrm{kg}$ (moderate); mass flow = $1 \mathrm{~kg} / \mathrm{min}$ (careful pouring); handling energy = 1 (equivalent release as in dustiness test); local emission controls = 1 (no control); pouring amount $=2.5 \mathrm{~kg}$ (poured from $1 \mathrm{~kg}$ bags, 9 minutes between pourings); room volume $=20 \mathrm{~m}^{3}$ (small room); ventilation rate $=2 \mathrm{~h}^{-1}$. The results of the modelling are reported in Table 2.

\section{ES 3 involving application of $\mathrm{CuO}$ wood coating to the substrate}


Because the Cu-based acrylic formulation is highly viscous it is applied to the substrate by a brush. Release of respirable (PM4.5) droplets of this solution is assumed to be insignificant during brush painting (ECHA 2016), so the inhalation exposure is assumed negligible. Workers performing the brushing are supposed to wear protective gloves to prevent direct skin exposure. If the gloves are worn correctly at all times, the skin exposure is insignificant. Hand-to-mouth exposure is also assumed to be negligible unless the worker touches mouth with contaminated gloves.

\section{ES 4 involving scraping, sanding and sawing wood treated with CuO preservative}

The old $\mathrm{CuO}$ wood preservative coating is typically removed before surface treatment. Because the dry coating is viscoelastic (elasticity modulus of the matrix is $10^{-7} \mathrm{~Pa}$ ) the coating is likely removed by scraping, which produces an insignificant amount of respirable particles: the smallest $10 \%$ size fraction of particles were $20 \mu \mathrm{m}$ in size (Nowack et al. 2016).

Emission rates were estimated based on sanding and drilling release experiments, which were used to represent also sawing operations and are described in the Supporting Information (cf. section SI2). The exposure levels were estimated based on these data by means of a single and two box (Hewett and Ganser 2017) models. The parameters used for modelling of sanding are the following: Emission rate = $20 \mu \mathrm{g} / \mathrm{sec}$ where $2 \%$ is $\mathrm{CuO}_{2}$ (sanding disc dimeter $150 \mathrm{~mm}$, grit size 80, rotation speed $1550 \mathrm{rpm}$, and contact force $17 \mathrm{~N}$ ); local emission controls = 1 (no control); room volume = $100 \mathrm{~m}^{3}$ (outdoor); FF ventilation rate $=10 \mathrm{~h}^{-1}$ (still air), near-field volume $=8 \mathrm{~m}^{3}$ after Cherrie $(1999)^{20}$; near-field air flow $=10$ $\mathrm{m}^{3} / \mathrm{min}$. This resulted to a near-field (NF) concentration of $93 \mu \mathrm{g} / \mathrm{m}^{3}$ during continuous process. The results of the modelling are reported in Table 2.

\section{ES 5 involving transfer to consumers' skin from surfaces by rubbing}

Consumers are assumed to be handling painted wood with their hands without wearing protective gloves, which can lead to direct skin exposure and subsequent inadvertent ingestion by touching the area around the mouth. Hand exposure was assessed by conducting dermal transfer tests in the SUN project by means of the surface wiping method based on the NIOSH guideline Elements on Wipes: Method 9102 (NIOSH 2003). The experimental set-up and the obtained results are described in detail in Mackevica et al. (submitted) and are outlined in the Supporting Information (cf. section SI2). 
Perioral exposure was estimated using a modified version of the Ingestion Exposure Tool (iEAT) (Gorman et al. 2012), assuming that a person touches a wood surface painted with $\mathrm{CuO}$ that has released $\mathrm{CuO}$ particles as a consequence of wearing and touches inadvertently the area around the mouth with subsequent ingestion by licking. The transfer efficiency of nanomaterials from finger tips to the perioral area was estimated experimentally. A worst case was assessed, where all the copper released from the wood is transferred to the finger tips. Each surface to hand event was presented as a hypothetical scenario were someone (with low or high hand moisture) touches the wood and then touches the perioral area. We assumed the finger area of contact was $1 \mathrm{~cm}^{2}$ and the perioral area of contact also 1 $242 \mathrm{~cm}^{2}$.

ES 11 involving children exposed directly to the $\mathrm{Cu}_{2}(\mathrm{OH})_{2} \mathrm{CO}_{3}$ impregnated wood by skin transfer of copper to the month and related ingestion

The most likely place for children to come into contact with copper-based impregnated wood is a playground, where its skin can be exposed to copper with subsequent transfer to the mouth and related ingestion. Estimations of children exposure have been provided by Platten et al. (2014), where the wood surface area a child would come into contact with during a typical visit to a playground has been estimated along with potential transfer, ingested concentration per playground visit and number of visits per week.

\section{ES 13 involving leaching during contact with water and related potential human exposure}

252 General population can come in contact with nano-scale $\mathrm{CuO}$ or $\mathrm{Cu}_{2}(\mathrm{OH})_{2} \mathrm{CO}_{3}$ released by the wood 253 during contact with water. To estimate the amount and form (particle or ion) of released copper, 254 leaching experiments were performed in the SUN project according to the European standard EN 84 255 (ISO 1997), which describes an accelerated aging test of pine specimens treated with wood preservative 256 formulations for simulating exposure to water (ISO 1997). The investigated material was the acrylic 257 coating containing $1.5 \% \mathrm{CuO}$ and $42.5 \% \mathrm{TiO}_{2}$ (pigment grade, non-nano) which was applied on pine 258 wood (dimension: $2.6 \times 2.7 \times 1.1 \mathrm{~cm}$ ). The result from applying the test showed that the released copper 259 was solely in ionic form (Pantano et al. 2018).

260 In the case of nano $\mathrm{Cu}_{2}(\mathrm{OH})_{2} \mathrm{CO}_{3}$, Platten et al. (2014) reported results from leaching tests indicating that 261 mostly ionic copper (> 95\%) was released from the treated wood and that the particulate copper that was released is attached to cellulose and is therefore not free in the leaching waters. 
Based on these results, the human exposure to nanoparticles leaching during contact of CuO coatings and $\mathrm{Cu}_{2}(\mathrm{OH})_{2} \mathrm{CO}_{3}$ impregnations with water was considered negligible.

\subsubsection{Derivation of exposure distributions}

266 The above exposure levels were used to generate an exposure distribution $\left(E X P_{i}\right)$ for each scenario $i$ by means of SUNDS. When only deterministic values were available, normal or lognormal distributions were used to describe the probabilistic distribution of exposure as recommended by the US Environmental Protection Agency (US EPA 2001). Such distributions were created around the available deterministic values by fitting a one order of magnitude (+/-50\%) wide confidence interval around the mean exposure estimate. The reason for this is that the exposure levels were estimated based on

272 measurements or models, which introduce uncertainties in the $\operatorname{EXP}_{\mathrm{i}}$. Indeed, measurements are obtained by instruments, which present known errors, but many other aspects (e.g. preparing the samples, positioning of the instrument) add more uncertainties (often larger than the instrument errors). Moreover, the application of the one box and two box exposure models (Ganser and Hewett 2017) also introduced uncertainties associated with certain assumptions.

\subsubsection{Hazard assessment}

\subsubsection{Hazard identification}

279 To identify the hazards of $\mathrm{CuO}$ and $\mathrm{Cu}_{2}(\mathrm{OH})_{2} \mathrm{CO}_{3}$ nanoparticles, a literature review was peformed, which 280 showed that dedicated in vivo inhalation or oral studies that considered multiple exposure doses (and 281 were therefore suitable for dose-response assessment) did not exist (Gosens et al. 2016). Therefore, we 282 designed and performed short-term inhalation and short-term oral studies in order to derive subacute 283 data that according to the REACH Guidance on Chemical Safety Assessment (ECHA 2008) and the 284 Guidance on Biocides Legislation (ECHA 2017) can be extrapolated for use in long-term HHRA. The used 285 pristine nanomaterials and dispersions were the same described in 2.1. The study designs are only 286 shortly outlined in this section as they are described in detailed in Gosens et al (2016) and De Jong et al 287 (submitted).

\section{Short-term inhalation exposure}

After an acclimatization period, rats (8 weeks old, HsdCpb: WU) were exposed nose-only to a single 290 generated exposure concentration of $\mathrm{CuO}$ nanomarticles or to clean air as a control for 5 consecutive days. By exposing the animals for various durations ( $18 \mathrm{~min}, 36 \mathrm{~min}, 90 \mathrm{~min}, 3 \mathrm{~h}$, and $6 \mathrm{~h}$ ), different dose 
292 levels were obtained. A $6 \mathrm{~h}$ concentration equivalent was derived by multiplying the duration of 293 exposure by the exposure concentration (designated as dose $\mathrm{C} \times \mathrm{T}$ ) and scaling it to the highest exposure 294 duration of $6 \mathrm{~h}$ to $13.2 \mathrm{mg} / \mathrm{m}^{3}$ (for animals dedicated for toxicological examination) or $11.6 \mathrm{mg} / \mathrm{m}^{3}$ (for 295 animals dedicated for organ burden analysis). Repeated exposures to CuO nanoparticles via inhalation 296 resulted in a linear increase in the determined lung burden, justifying the applied C x T concept.

\section{Short -term oral exposure}

298 Male rats (RjHan: WI, bred Specific Pathogen Free, barrier maintained during experiment) of 8-9 weeks 299 old were obtained from Janvier Labs (Le Genest-Saint-Isle, Saint Berthevin, France). The CuO nanopaticle 300 dispersions were orally administered by gavage using the following exposure doses: vehicle control, 1, 2, $3014,8,16,32, \mathrm{mg} / \mathrm{kg}$ body weight (b.w.) and a pilot study with $64 \mathrm{mg} / \mathrm{kg} \mathrm{b.w.} \mathrm{The} \mathrm{doses} \mathrm{were} \mathrm{chosen}$ 302 based on information in the literature of soluble non-nano $\mathrm{CuSO}_{4}$, which indicated a No-observed 303 Adverse Effect Level (NOAEL) of $16.3 \mathrm{mg} / \mathrm{kg}$ (Hébert 1993). The dose was administered as $0.1 \mathrm{ml}$ per 20 $304 \mathrm{~g}(1 \mathrm{ml}$ per $200 \mathrm{~g})$. In an additional study one group of animals $(\mathrm{n}=4)$ was exposed to a high dose of 512 $\mathrm{mg} / \mathrm{kg}$ b.w. For the $\mathrm{Cu}_{2}(\mathrm{OH})_{2} \mathrm{CO}_{3}$ nanoparticles the administered doses were, vehicle control, 4, 8, 16, 32, 64, and $128 \mathrm{mg} / \mathrm{kg}$ b.w. The animals were treated on five consecutive days (days 1-5) and autopsy was performed 24 hours after the last oral administration (day 6). In addition, a recovery period of 3 weeks was included in the experiments to evaluate recuperation and possible persistence of the nanomaterials in the body. Autopsy of the recovery groups was performed on day 26, after three weeks of recovery.

\subsubsection{Dose-response assessment}

311 The dose-response assessment of the raw inhalation data was not performed by means of SUNDS 312 because it was done by Gosens et al. (2016) using the PROAST model. PROAST estimates a benchmark 313 dose (BMD), which corresponds to a pre-defined benchmark response (BMR). The uncertainty of the 314 BMD is reflected by providing a 90\% confidence interval with an upper (BMDU) and lower (BMDL) limit.

315 The dose-response assessment of the ingestion data was also not performed by means of SUNDS, but by 316 De Jong et al (submitted), who derived a Lowest Observed Adverse Effect Level (LOAEL) for decrease of 317 total body weight, which was then divided by an uncertainty factor (UF) of 3 to calculate a NOAEL. 
The BMD and NOAEL values derived from the two studies were imported in SUNDS, and used by the system as PoD, which were "corrected" to account for exposure duration differences between the animal experiments and the ES. In addition, allometric scaling was performed in case of oral studies to consider physiological differences between the experimental animals and humans. These "corrected"

322 probability distributions were then extrapolated to human effect threshold distributions by applying 323 appropriate inter- and intra-species extrapolation factors (EF) (ECHA 2008).

324 The correction, allometric scaling and extrapolations were performed by means of APROBA, which is a 325 Microsoft Excel tool developed by the World Health Organisation's International Programme on Chemical Safety (IPCS-WHO) and is programmed in SUNDS. It is able to perform approximate probabilistic (as well as deterministic) analysis of human dose extrapolation starting from animal doseresponse results. The result of the probabilistic hazard assessment is a human effect threshold, called human dose $H D_{M}^{I}$ at which a fraction I of the human population shows an effect of magnitude $\mathrm{M}$ after chronic exposure, with a specific confidence interval (e.g. 90\%). This fraction / represents the sensitive target population, which is the portion of population that is more vulnerable to effects of exposure to the substance due to e.g. age or poor health status. APROBA contains default algorithms and values for performing correction and allometric scaling based on input information (cf. 3.2.2 and Table 4) (IPCSWHO 2014). It also uses default extrapolation factors, which were proposed by the IPCS-WHO and are reported in Table 1.

Insert Table 1 here

\subsubsection{Risk characterization \& Uncertainty analysis}

338 Risk was calculated by means of SUNDS based on the Risk Characterization Ratio $\left(R C R_{i, M}^{I}\right)$ approach, 339 which takes into account uncertainty and variability related to the incidence goal sensitive populaiton. $340 R C R_{i, M}^{I}=E X P_{i} / H D_{M}^{I}$, where $E X P i$ represents an exposure level for scenario $i$. The $R C R_{i, M}^{I}$ distribution 341 is classified as "non-acceptable" when it is above 1 for more than $10 \%$ of the sensitive population. The 342 variability related to the rest of population is not taken into account in $H D_{M}^{I}$ because when the sensitive 343 population is at risk we assume that also the general population is at risk. The exposure situation "needs 344 further consideration" when the $R C R_{i, M}^{I}$ is above 1 in $5 \%$ to $10 \%$, and the risk is "acceptable" when it is 345 above 1 for less than $5 \%$ of the sensitive population. These risk acceptability classes were defined based 346 on the literature, which suggests that (in the case of probabilistic risk assessment) the risk can be 
acceptable if the $90^{\text {th }}$ percentile of the population is safe, but more conservative values (i.e. the $95^{\text {th }}$ percentile or the $99^{\text {th }}$ percentile) can also be selected (USEPA 2001; USEPA 2014a; USEPA 2014b).

RCR distributions were generated for each of the ES by sampling the $H D_{M}^{I}$ and EXPi distributions in over 10000 Monte Carlo simulations. The probablity distribution of the RCR is affected by 1) the assumptions/considerations applied in the probabilistic hazard assessment and 2) the uncertainties associated with the exposure estimations. In the first case, selecting a specific population incidence goal (e.g. 5\%) in the dose-response assessment implies that the resulting probabilistic distribution of the RCR protects $95 \%$ of the population, thus the RCR probability distribution represents the variability and uncertainty around the $95 \%$ of the assessed population.

The contribution of different sources to the overall uncertainty in the RCR was estimated for each ES by means of Monte Carlo. In each of the 10000 simulations RCR was numerically estimated by randomly sampling 10000 elements from the distributions of the PoD, exposure and UF. The contribution of each of these factors to the uncertainty in the risk estimate was quantified by assessing the level of correlation between the factor and the resulting RCR by means of the squared Spearman's rank correlation coefficient ${ }^{8}$.

\section{Results}

\subsection{Exposure assessment}

36413 ES were formulated that covered the entire lifecycles (i.e. synthesis, formulation, use, end-of-life) of our case-study products: $\mathrm{CuO}$-based coating paint and $\mathrm{Cu}_{2}(\mathrm{OH})_{2} \mathrm{CO}_{3}$-containing impregnation (Table 2).

The exposure assessment of the CuO-based coating demonstrated that release of nanoparticles is 367 possible at each lifecycle stage and can lead to both worker and consumer exposure in different 368 formulations: as nanopowder, as liquid paint, or as a cured surface coating on wood. The handling of dry 369 powders led to some significant exposure potential in the formulation lifecycle stage. If paint spraying is 370 avoided, inhalation exposure to paint is assumed negligible during its application, but dermal and oral 371 exposure could be relevant for both workers and consumers either via accidental dermal deposition 372 when treating (painting) the wood or via hand-to-mouth (i.e. inadvertent oral) exposure. However, 373 according to the latest studies dermal exposure is insignificant (Platten et al. 2016). Moreover, the 374 dermal transfer testing of the painted wooden blocks (cf. 2.2.2) showed that there was nearly no release 375 of nanoscale $\mathrm{CuO}$ from the paint matrix during surface wiping tests (Mackevica et al.). However, after 
sanding of the paint surface, the observed $\mathrm{CuO}$ release was magnitudes higher. Accordingly, inhalation and inadvertent oral exposures were assessed in the case of occupational and consumer use during sanding activities and the results were used to represent also sawing operations.

The analysis of the literature on $\mathrm{Cu}_{2}(\mathrm{OH})_{2} \mathrm{CO}_{3}$-impregnated wood showed that the release of copper nanoparticles is typically negligible. The US EPA report provided an estimate of exposure for the concerning ES11 that involves children exposed directly to the treated wood by skin contact, transfer of copper to the month and subsequent ingestion (Platten et al. 2014). Moreover, two other common exposure pathways were identified and assessed: leaching during contact with water and transfer during physical contact (cf. Table 2).

Insert Table 2 here

We used SUNDS to generate EXP i probability distributions for each ES based on the estimated exposure levels, which demonstrated significant exposure potential for scenarios 2, 4 and 11 (Table 3). To account for unknown uncertainties due to measurement and modelling errors we established a one order of magnitude wide confidence interval around the deterministic inhalation exposure estimates for ES2 and ES4 $\left(0.026 \mathrm{mg} / \mathrm{m}^{3}\right.$ and $0.36 \mathrm{mg} / \mathrm{m}^{3}$, respectively) and fitted the corresponding normal distributions. In ES11, starting from an exposure of $1.11 \mathrm{mg} /$ day derived by averaging three visits to the playground over a week (Platten et al. 2014), we built a normal distribution representing uncertainty in the number of weekly visits characterized by the $5^{\text {th }}$ percentile at $1.11 / 3 \mathrm{mg} /$ day and the $95^{\text {th }}$ percentile at 1.11 $\mathrm{mg} /$ day. This bell-shaped curve was then divided by a uniform mixture of normal distributions representing the variability of weights of children (girls) aged from 8 to 36 months (mean: $10.95 \mathrm{~kg}$, SD: $\left.2.18, \mathrm{Cl}_{5 \%}: 7.6 \mathrm{~kg}, \mathrm{Cl}_{95 \%}: 14.68 \mathrm{~kg}\right)$.

Insert Table 3 here

\subsection{Hazard Assessment}

\subsubsection{Hazard identification}

The detailed results from the short-term inhalation exposure are available in Gosens et al. (2016), while the results from the short-term oral exposure are reported in De Jong et al (submitted). Therefore, only the main findings of relevance for the dose-response analysis (cf. 3.2.2) are outlined below. 


\section{Short-term inhalation exposure}

404 Twenty-four hours after a 5-day exposure to $\mathrm{CuO}$ pristine nanoparticles, dose-dependent lung 405 inflammation and cytotoxicity were observed as well as histological alterations of the nose epithelium.

406 Lung histopathological examinations indicated alveolitis, bronchiolitis, vacuolation of the respiratory 407 epithelium and emphysema in the lung starting at a $6 \mathrm{~h}$-concentration equivalent of $2.4 \mathrm{mg} / \mathrm{m}^{3}$.

408 After a recovery period of 22 days, limited lung inflammation was still observed leaving a small but 409 significant elevation of macrophages in the airspace (at the highest dose of $13.2 \mathrm{mg} / \mathrm{m}^{3}$. This 410 inflammation was not accompanied by pathological changes or elevated biochemical markers of fibrosis.

411 The histological alterations of the olfactory epithelium in the nose restored completely after 22 days. No 412 histopathological changes were detected in the brain, olfactory bulb, spleen, kidney and liver. In 413 conclusion, a 5-day, 6-hour/day exposure equivalent to an aerosol of agglomerated CuO nanoparticles 414 resulted in a dose-dependent toxicity in rats, which almost completely resolved during a 3-week postexposure period. The data for all endpoints measured were compared via the BMD calculated by PROAST. This allowed a ranking of the relative sensitivity of each endpoint to the inhaled CuO

417 nanoparticles with biochemical markers and inflammatory cell number in the bronchoalveolar lavage 418 fluid providing to be the most sensitive indicators for lung toxicity (Gosens et al. 2016) .

\section{Short-term oral exposure}

420 Copper oxide: In the dose response study with a maximum dose of $64 \mathrm{mg} / \mathrm{kg}$, no signs of toxicity were 421 noted. After treatment of 5 consecutive days there was no difference in body weight between day 1 422 (start of treatment) and day 6 (24 hours after end of treatment). In the addional group of animals 423 treated with $512 \mathrm{mg} / \mathrm{kg}$ some indications for toxicity were observed based on changes in the body 424 weight. Moreover, the results of the clinical chemistry showed that at day 6 alterations in the level of 425 alkaline phosphatase and aspartate aminotransferase enzymes indicated the presence of liver toxicity. 426 At the dose of $64 \mathrm{mg} / \mathrm{kg}$ lactate dehydrogenase levels were also increased indicating cell and organ 427 damage. Animals treated with $512 \mathrm{mg} / \mathrm{kg}$ showed similar alterations in clinical chemistry (low level of 428 alkaline phosphatase, high level of aspartate aminotransferase, and high level of lactate 429 dehydrogenase), and histopathological alterations in the liver (e.g. inflammation, hepatocellular 
hypertrophy, hepatocellular necrosis) thus supporting the data of the dose response study. Therefore,

431 the dose $512 \mathrm{mg} / \mathrm{kg}$ was taken as the LOAEL.

432 Copper carbonate: For $\mathrm{Cu}_{2}(\mathrm{OH})_{2} \mathrm{CO}_{3}$ nanoparticles a dose response study was performed with the 433 highest dose being $128 \mathrm{mg} / \mathrm{kg}$ b.w. Repeated (5 times) oral administration of the highest dose induced 434 severe toxic responses in the treated animals as indicated by the behaviour of the animals, frequent 435 washing and piloerection. Based on these observations the animals scheduled for prolonged observation 436 (autopsy after a recovery period at day 26 after treatment) were autopsied prematurely at days 6 and 7, respectively 24 and 48 hours after the last (day 5) treatment.

438 For animals treated with a dose up to $64 \mathrm{mg} / \mathrm{kg} \mathrm{b.w.} \mathrm{both} \mathrm{at} \mathrm{day} 6$ and day 26 after treatment both body and organ weights did not show a difference with the vehicle treated control animals. These results were consistent with the results from the haematological and clinical chemistry analyses. However, for the animals treated with $128 \mathrm{mg} / \mathrm{kg}$ b.w. at day 6 a decrease in body weight and weight of heart, liver, spleen, thymus was obeserved whereas adrenal weights were increased, the latter probably indicating a stress response due to the toxicity of the $\mathrm{Cu}_{2}(\mathrm{OH})_{2} \mathrm{CO}_{3}$ nanoparticles. In addition, several clinical chemistry parmeters in the blood were affected (e.g. white blood cell increase, red blood cell decrease, and increases in ALT, AST, and LDH) Histopathological lesions were observed in various organs, notably the liver (hepatocellular vacuolation, hypertrophy, and necrosis, and single cell necrosis) (de Jong et al.).

\subsubsection{Dose-response Analysis}

\section{Deriving the PoD}

449 The inhalation study argued that changes in the total number of inflammatory cells in the BAL can be considered a critical endpoint for inhalation risk assessment and proposed a BMR of $100 \%$ based on previous studies (Gosens et al. 2016). This BMR was used to calculate a BMDL of $0.16 \mathrm{mg} / \mathrm{m}^{3}$ and a

452 BMDU of $0.29 \mathrm{mg} / \mathrm{m}^{3}$ by means of PROAST (Gosens et al. 2016). This BMD lognormal distribution was 453 used as the PoD for risk assessment.

454 As far as CuO ingestion toxicity is concerned, based on the short-term oral exposure De Jong et al 455 (submitted) a LOAEL for decrease of total body weight corresponding to $512 \mathrm{mg} / \mathrm{kg}$ was estimated. We 456 divided this value by an UF of 3 to calculate a NOAEL of $170.67 \mathrm{mg} / \mathrm{kg}$. The short term oral study of the $457 \mathrm{Cu}_{2}(\mathrm{OH})_{2} \mathrm{CO}_{3}$ derived a LOAEL of $128 \mathrm{mg} / \mathrm{kg}$, which we similarly divided by an UF of 3 to estimate a 
NOAEL of $42,67 \mathrm{mg} / \mathrm{kg}$ b.w. These NOAEL values were corrected by means of APROBA (when needed) for differences in human and experimental exposure conditions and in respiratory volumes between experimental animals (at rest) and humans (light activity) and then used as PoD for risk assessment.

\section{Selecting the Uncertainty Factors}

462 The seleted UF for CuO are for interspecies scaling, interspecies toxicokinetics and toxicodynamics, 463 intraspecies differences and differences in duration of exposure for both ingestion and inhalation. The 464 seleted UF for $\mathrm{Cu}_{2}(\mathrm{OH})_{2} \mathrm{CO}_{3}$ are interspecies scaling, interspecies toxicokinetics and toxicodynamics, 465 intraspecies differences and differences in duration of exposure for the ingestion pathway. The probabilistic distributions of these factors are the default values suggested by APROBA and reported in

467 Table 1.

\section{Deriving the distributions of HD}

The PoD were used as inputs to APROBA, which was applied with the above inter- and intra-species scalling and and uncertainty factors as shown in Table 4 to derive lognormal distributions of long-term HDs for local and systemic effects due to both inhalation and ingestion of CuO and only ingestion of $472 \mathrm{Cu}_{2}(\mathrm{OH})_{2} \mathrm{CO}_{3}$. The results are reported in Table 5.

Insert Tables 4 and 5 here

\section{$474 \quad 3.3$ Risk characterization \& Uncertainty analysis}

475 Figure 2 and Table 6 display the risks along the lifecycles of the investigated products and the associated 476 sources of uncertainty estimated by means of SUNDS. 3 out of the 13 occupational and consumer ES 477 resulted in $\mathrm{RCR}$ distributions $\geq 1$ (i.e. risk present). The formulation stage ES2 had a high probability of 478 risk compared to the other scenarios in the formulation lifecycle stage, with nearly $93.33 \%$ of the 479 Monte-Carlo simulation results being $\geq 1$ (i.e. $6.67 \%$ of the RCR resulted in no risk to the exposed 480 sensitive population). Nearly $95.79 \%$ of the variation in this result were caused by uncertainty in the 481 UFs, mainly the factor used for extrapolation from subacute to chronic effects (62.77\%). In the use-stage 482 ES4, a worst-case exposure estimation of $0.32 \mathrm{mg} / \mathrm{m}^{3}$ determined a non-acceptable inhalation risk for $48399.87 \%$ of the sensitive population of both workers and consumers. $95.8 \%$ of the uncertainty in this result was again due to the UFs as the main underlying source was the extrapolation from subacute data 
to chronic effects. The perioral intake in ES4, instead, resulted in a safe scenario even for the most sensitive population. In contrast, the ES11 involving children exposed to the $\mathrm{Cu}_{2}(\mathrm{OH})_{2} \mathrm{CO}_{3}$ through inadvertent ingestion is non-acceptable for $8.48 \%$ of the population. Similarly to the other concerning scenarios $94.08 \%$ of the uncertainty in this result was caused by the UFs, but this time the contribution of the underlying sources was different: extrapolation from subacute to chronic effects $=41.62 \%$; extrapolation from NOAEL to $\mathrm{BMD}=22.69 \%$; intraspecies extrapolation $=20.26 \%$; interspecies toxicokinetics $/$ dynamics $=11.34 \%$; allometric scaling $=0.17 \%$. The remaining $3.92 \%$ were from variation in exposure factors (i.e. exposure of the substance to sensitive children accounted for $2.86 \%$ of the uncertainty, while children weights contributed for $1.06 \%)$. The full characterization of the distributions used to perform the Uncertainty assessment is presented in the Supporting Information (Section S3), together with the complete results for ES2 (Inhalation rout of exposure), ES4 (Inhalation and Perioral routes of exposure) and ES11 (Oral route of exposure).

Insert Figure 2 and Table 6 here

\section{Discussion}

This is the first quantitative HHRA of nanoscale $\mathrm{CuO}$ and $\mathrm{Cu}_{2}(\mathrm{OH})_{2} \mathrm{CO}_{3}$ used for antimicrobial and antifungal treatment of wood. In contrast to the more classical deterministic approach our probabilistic methodology was able to discriminate and communicate the different sources of uncertainty in the risk analysis (Figure 1) to better inform the generation of additional data and/or the adoption of adequate risk management measures.

Specifically, it was possible to assess the uncertainty in the dose-response data by means of parametric bootstrapping. This enabled us to discover the largest source of uncertainty in the assessment, which was due to the extrapolation of the BMD derived from subacute animal experiments to long-term human HD. Therefore, in order to increase the confidence in our results it is important to repeat the analysis once (sub)chronic in vivo inhalation and ingestion data become available.

Other considerable sources of uncertainty were the inter- and intraspecies EF. These default values were defined for regular chemicals based on historical precedence and if we assume that the $\mathrm{CuO}$ and $\mathrm{Cu}_{2}(\mathrm{OH})_{2} \mathrm{CO}_{3}$ nanoforms act according to different mechanisms of toxicity, then these factors may turn 
out to be inacurate. In order to reduce this type of uncertainty it may be necessary to establish nano-

514 specific EF based on extensive analysis of the available physicochemical and toxicity data for

515 nanomaterials. This requires the development of data management and curation capabilities to check 516 the quality of data prior to their analysis.

517 The results from the dose-response analysis largely depend on the BMR. There is a lack of consensus 518 among toxicologists regarding what effect size may demarcate adverse from non-adverse and there is 519 an agreement that the BMR may differ significantly among endpoints. Therefore, some authors 520 suggested the evaluation of an uncertainty distribution for the BMR (Van Der Voet and Slob 2007), but 521 we did not do this in our study. Instead, we used predefined values, which helped to communicate 522 which BMR corresponds to which BMD distribution, but prevented us from considering this important 523 parameter in the uncertainty analysis.

524 Other uncertainty arises from the fact that from the short-term exposure studies it is difficult to predict 525 that no (sub)chronic endpoints like sustained inflammation or fibrosis will be affected at longer 526 exposures. In the short-term inhalation study, we found that lung inflammation was not completely 527 resolved after 22 days but did not lead to fibrosis, while copper levels in the lung returned to baseline 528 levels (Gosens et al. 2016).

529 The exposure assessment of the dry nanoscale powders in this study was determined for worst-case 530 scenarios, as risk management measures (e.g. emission controls, efficiency of local exhaust ventilation) 531 that may reduce their airborne concentrations were not considered. Therefore, the impact of possible 532 overestimations of exposures from powder handling in the workplace may have been significant in 533 determining the high estimated risks associated with these scenarios. Therefore, these risks could be 534 easily managed by applying appropriate risk management measures (e.g. engineering controls, personal 535 protective equipment).

536 The potential risks of ES11 that involves children ingesting $\mathrm{CuO}$ or $\mathrm{Cu}_{2}(\mathrm{OH})_{2} \mathrm{CO}_{3}$ nanoparticles by skin 537 contact, transfer of copper to the month and related ingestion would be more difficult to control. In this 538 case, the potentially most effective measures to be considered involve safety by design measures to 539 reduce the release potential and/or the hazard of the material as well as consumer labelling and safety 540 instructions. 
541 Other sources of uncertainty in the exposure assessment may result from the fact that only external 542 doses were considered in this study, while due to insufficient data the uptake and the translocation of 543 the substances in the organism were not considered. Particle size distributions strongly influence the 544 deposition pattern of nanoparticles in the lungs and their dissolution kinetics in cases of soluble particles 545 such as $\mathrm{CuO}$ or $\mathrm{Cu}_{2}(\mathrm{OH})_{2} \mathrm{CO}_{3}$ (Gosens et al. 2016).

546 There are also considerable uncertainties in the measured external exposure concentrations in the air as 547 they may quickly decline due to aggregation, agglomeration or surface deposition (Schneider and Jensen 548 2009). This means that nanoscale fractions measured close to the emission source may be eliminated 549 by the time the particles are deposited in the lungs. Some specific sources of uncertainty that were not 550 explicitly defined in this study include for example the time length of each work activity, the time-length 551 of pauses between work activities. Exact values of these parameters will not always be known but can 552 have a significant influence on nano-specific transformation processes such as aggregation and thus the 553 inhalation exposure to nanoparticles.

554 In the lungs or the intestine the particles might completely dissolve, which would mean that only ions 555 are uptaken in the systemic circulation and are translocated to the secondary organs. These phenomena 556 could differ between species and the effects observed in animals could follow different mechanisms of 557 toxicity as compared to the actual effects in humans. In order to reduce these uncertainties it is 558 essential to perform kinetic studies and to appropriately measure or model the dissolution as well as the 559 absorption, distribution, metabolisation and excretion (ADME) kinetics of the investigated substances. 560 The results from the kinetic studies that we performed in the SUN project showed that after short-term 561 inhalation of $\mathrm{CuO}$ pristine nanoaprticles, no other organs besides the nose and lung were affected based 562 on histological analysis and organ weights. This could be explained by the lack of any increase in $\mathrm{Cu}$ 563 levels compared to background levels in the liver, blood, brain, bone marrow, heart, kidney, and spleen 564 at the applied exposure levels. After oral adminstration of $\mathrm{CuO}$ nanoparticls at day 6 increased levels of $565 \mathrm{Cu}$ was noted mainly in liver and lung starting at a dose of $32 \mathrm{mg} / \mathrm{kg} \mathrm{b.w}$. After oral adnistration of $566 \mathrm{Cu}_{2}(\mathrm{OH})_{2} \mathrm{CO}_{3}$ nanoparticles increased $\mathrm{Cu}$ levels were observed in liver, lung, kidney, spleen, thymus, 567 mesenteric lymp nodes, and to a lesser extent in testes and brain. This clearly shows that the two 568 investigated materials have very different ADME profiles, but as long as we do not understand their 569 dissolution kinetics we can only guess what are the underlying reasons for this. 
In general nanomaterials (incl. $\mathrm{CuO}$ and $\mathrm{Cu}_{2}(\mathrm{OH})_{2} \mathrm{CO}_{3}$ ) are offered in many different grades that are

571 optimized in terms of physicochemical properties for integration into specific applications. This study is a

572 case-specific risk assessment where the nanomaterials used in the exposure and the hazard studies are

573 similar. This is however often not the case in order to avoid excessive case-by-case testing we should

574 search for posibilities to group them based on physico-chemical, release, exposure, bio-kinetic or

575 toxicological information in order to facilitate read-across, which could reduce testing costs and the use

576 of experimental animals.

\section{5. Conclusions}

578 Our assessment demonstrated unacceptable inhalation risks of $\mathrm{CuO}$ for worst-case ES involving handling 579 of dry powders and sanding operations. In addtion, we identified potentially unacceptable ingestion risks for the sensitive populaion of childred exposued to $\mathrm{Cu}_{2}(\mathrm{OH})_{2} \mathrm{CO}_{3}$ nanoparticles by hand to mouth

581 contact with impregnated wood. It should be noted, however, that there are significant uncertainties in 582 these results, which should be resolved by additional testing. Therefore, the conclusion "unacceptable risk" may stem from the safety margin of extrapolations to fill data gaps and is therefore not a proof of 584 actual risks.

585

Our analysis demonstrated that the main source of uncertainty is the extrapolation from subacute to 586 long-term exposure, which was necessary due to the lack of (sub)chronic in vivo studies with CuO and $587 \mathrm{Cu}_{2}(\mathrm{OH})_{2} \mathrm{CO}_{3}$. Considerable uncertainties also stemmed from the use of default inter- and intra-species 588 UF for chemicals. The proposed approach is currently suited only for case-by-case risk assessments, but 589 will be extended to enable also grouping and read-across for more efficient analysis.

590 Acknowledgements

591 This research was funded by the European Commission in the frame of the FP7 project SUN (grant 592 agreement No. 604305). The authors would like to thank Bas Bokkers and Wout Slob for their valuable 593 advice regarding probabilistic risk assessments.

\section{Declaration of interest}

595 The authors report no conflicts of interest.

\section{References}


598

599

600

601

602

603

604

605

606

607

608

609

610

611

612

613

614

615

616

617

618

619

620

621

622

623

624

625

626

Civardi, C., Schwarze, F. W. M. R. and Wick, P. (2015) 'Micronized copper wood preservatives: An efficiency and potential health risk assessment for copper-based nanoparticles', Environmental Pollution, 200(Supplement C), 126-132.

Clausen, C. A. (2007) Nanotechnology: Implications for the wood preservation industry, Stockholm, Sweden.

de Jong, W., Stone, V., Cassee, F. and Gosens, I. 'A 28-day oral toxicity study in rats with copper oxide and copper carbonate nanoparticles', submitted.

ECHA (2008) Guidance on information requirements and chemical safety assessment. Chapter R.8: Characterisation of dose concentration -response for human health, European Chemicals Agency.

ECHA (2016) Recommendation no. 10 of the BPC Ad hoc Working Group on Human Exposure: The most appropriate model to be used for the scenario of non-professional application of paints by brushing and rolling, Helsinki, Finland: European Chemicals Agency.

ECHA (2017) Guidance on the Biocidal Products Regulation - Volume III Human Health - Assessment \& Evaluation (Parts $B+C$ ), Helsinki, Finland: European Chemicals Agency.

Evans, P., Matsunaga, H. and Kiguchi, M. (2008) 'Large-scale application of nanotechnology for wood protection', Nat Nano, 3(10), 577-577.

Fonseca, A., Kuijpers, E., Kling, K., Levin, M., Koivisto, A., Nielsen, S., Fransman, W., Yu, Y., Antipov, A., Jensen, K. and Koponen, I. 'Particle release and control of worker exposure during laboratoryscale synthesis, handling and simulated spills of manufactured nanomaterials in fume-hoods', Journal of Nanoparticle Research (submitted). 
633

634

636

637

641

642

643

644

645

646

647

648

649

650

651

652

653 654

655

656

657

Freeman, B. M. H. and McIntyre, C. R. (2008) 'A Comprehensive Review of Copper-Based Wood Preservatives with a focus on new micronized or dispersed copper systems', Forest Products Journal, 58(11), 6-27.

Freeman, M. and Mcintyre, C. (2013) 'Micronized CopperWood Preservatives: Strong Indications of the Reservoir Effect. In: International Research Group on Wood Protection, pp. 18'.

Ganser, G. H. and Hewett, P. (2017) 'Models for nearly every occasion: Part II - Two box models', Journal of Occupational and Environmental Hygiene, 14(1), 58-71.

Gorman, M., Semple, S., W. Cherrie, J., Christopher, Y., Northage, C., Tielemans, E., Veroughstraete, V. and Van Tongeren, M. (2012) 'The Relationship Between Inadvertent Ingestion and Dermal Exposure Pathways: A New Integrated Conceptual Model and a Database of Dermal and Oral Transfer Efficiencies', The Annals of Occupational Hygiene, 56(9), 1000-1012.

Gosens, I., Cassee, F. R., Zanella, M., Manodori, L., Brunelli, A., Costa, A. L., Bokkers, B. G. H., de Jong, W. H., Brown, D., Hristozov, D. and Stone, V. (2016) 'Organ burden and pulmonary toxicity of nanosized copper (II) oxide particles after short-term inhalation exposure', Nanotoxicology, 1-12.

Hewett, P. and Ganser, G. H. (2017) 'Models for nearly every occasion: Part I - One box models', Journal of Occupational and Environmental Hygiene, 14(1), 49-57.

Hébert, C. (1993) NTP Technical Report on toxicity studies of cupric sulphate (CAS N7758-99-8) administered in drinking water and feed to F344/N rats and B6C3F1 mice, National Toxicology Program, U.S. Department of Health and Human Services.

IPCS-WHO (2014) Guidance document on evaluating and expressing uncertainty in hazard characterization, World Health Organisation.

ISO (1997) BS EN 84: Wood preservatives. Accelerated ageing of treated wood prior to biological testing. Leaching procedure, London, UK: British Standards Institution. 
Kartal, S. N., Green, F. and Clausen, C. A. (2009) 'Do the unique properties of nanometals affect leachability or efficacy against fungi and termites?', International Biodeterioration and Biodegradation, 63(4), 490-495.

662

663

664

665

666

667

668

669

670

671

672

673

674

675

676

677

678

679

680

681

682

683

684

685

686

687

Lebow, S. and Foster, D. (2005) 'Environmental concentrations of copper, chromium, and arsenic released from a chromated-copper-arsenate- (CCA-C-) treated wetland boardwalk', Forest Products Journal, 55(2), 62-70.

Mackevica, A, Olsson, M., Mines, P., Heggelund, L. and Hansen, S. 'Estimation of dermal transfer of nanoparticles from consumer articles by wipe sampling', submitted.

NIOSH (2003) 'Elements on wipes: Method 9102' in NIOSH Manual of Analytical Methods, National Institute for Occupational Safety and Health.

Nowack, B., Boldrin, A., Caballero, A., Hansen, S. F., Gottschalk, F., Heggelund, L., Hennig, M., Mackevica, A., Maes, H., Navratilova, J., Neubauer, N., Peters, R., Rose, J., Schäffer, A., Scifo, L., Leeuwen, S. v., von der Kammer, F., Wohlleben, W., Wyrwoll, A. and Hristozov, D. (2016) 'Meeting the Needs for Released Nanomaterials Required for Further Testing-The SUN Approach', Environmental Science \& Technology, 50(6), 2747-2753.

Pang, C., Hristozov, D., Zabeo, A., Pizzol, L., Tsang, M. P., Sayre, P. and Marcomini, A. (2017) 'Probabilistic approach for assessing infants' health risks due to ingestion of nanoscale silver released from consumer products', Environment International, 99, 199-207.

Pantano, D., Neubauer, N., Navratilova, J., Scifo, L., Civardi, C., Stone, V., von der Kammer, F., Müller, P., Sobrido, M. S., Angeletti, B., Rose, J. and Wohlleben, W. (2018) 'Transformations of Nanoenabled Copper Formulations Govern Release, Antifungal Effectiveness, and Sustainability throughout the Wood Protection Lifecycle', Environmental Science \& Technology, 52(3), 11281138. 
Pizzol, L., Hristozov, D., Zabeo, A., Basei, G., Wohlleben, W., Koivisto, J., Jensen, K. A., Fransman, W., Stone, V. and Marcomini, A. 'SUNDS probabilistic human health risk assessment methodology and its application to organic pigment used in the automotive industry', submitted.

Platten, W., Luxton, T., Gerke, S., Harmon, N., Sylvest, K., Rogers, B. and Rogers, K. (2014) Release of Micronized Copper Particles from Pressure Treated Wood Products, US Environmental Protection Agency.

Platten, W. E., Sylvest, N., Warren, C., Arambewela, M., Harmon, S., Bradham, K., Rogers, K., Thomas, T. and Luxton, T. P. (2016) 'Estimating dermal transfer of copper particles from the surfaces of pressure-treated lumber and implications for exposure', Science of the Total Environment, 548549, 441-449.

SCENIHR (2009) Risk assessment of products of nanotechnologies, Brussels, Belgium: Scientific Committee on Emerging and Newly Identified Health Risks.

Schneider, T. and Jensen, K. (2009) 'Relevance of aerosol dynamics and dustiness for personal exposure to manufactured nanoparticles', J Nanopart Res, 11(7), 1637-1650.

Steinfeldt, M. (2017) 'Hot Spot Release Mapping of Nanomaterials - A Visual Exposure Assessment Method for Preliminary Assessment', in New Tools and Approaches for Nanomaterials Safety Assessment, Malaga, Spain,

Subramanian, V., Semenzin, E., Hristozov, D., Zabeo, A., Malsch, I., McAlea, E., Murphy, F., Mullins, M., van Harmelen, T., Ligthart, T., Linkov, I. and Marcomini, A. (2016) 'Sustainable nanotechnology decision support system: bridging risk management, sustainable innovation and risk governance', Journal of Nanoparticle Research, 18(4), 1-13.

Tiarks, F., Frechen, T., Kirsch, S., Leuninger, J., Melan, M., Pfau, A., Richter, F., Schuler, B. and Zhao, C. L. (2003) 'Formulation effects on the distribution of pigment particles in paints', Progress in Organic Coatings, 48(2), 140-152. 
721 Tsang, M. P., Hristozov, D., Zabeo, A., Koivisto, A. J., Jensen, A. C. Ø., Jensen, K. A., Pang, C., Marcomini, 722 A. and Sonnemann, G. (2017) 'Probabilistic risk assessment of emerging materials: case study of 723 titanium dioxide nanoparticles', Nanotoxicology, 11(4), 558-568.

724

725 US EPA (2001) Risk Assessment Guidance for Superfund: Volume III - Part A, Process for Conducting 726 Probabilistic Risk Assessment, Washington DC, USA: US Environmental Protection Agency.

727

728 US EPA (2003) A Probabilistic Risk Assessment for Children Who Contact CCA-Treated Playsets and Decks, Washington DC, USA: US Environmental Protection Agency.

730

731 Van Der Voet, H. and Slob, W. (2007) 'Integration of probabilistic exposure assessment and probabilistic hazard characterization', Risk Analysis, 27(2), 351-371.

733

734 Van Leeuwen, C. and Vermeire, T. (2007) Risk assessment of chemicals: An introduction, Springer. 
739 Table 1. Generic Uncertainty (Extrapolation) Factors (UF) for different aspects of the dose-response assessment assuming lognormal uncertainty distributions. Source: IPCS-WHO guidance document on evaluation and communication of uncertainty in hazard characterisation (IPCS-WHO 2014).

\begin{tabular}{|c|c|c|c|c|}
\hline $\begin{array}{l}\text { Aspect of hazard } \\
\text { characterization }\end{array}$ & $\begin{array}{c}\text { Lognormal } \\
\text { P50 }\end{array}$ & $\begin{array}{c}\text { Lognormal } \\
\text { P95/P50 }\end{array}$ & $\begin{array}{c}\text { Lognormal } \\
\text { (P05, P95) }\end{array}$ & Comments \\
\hline \multicolumn{5}{|c|}{ PoD uncertainty for NOAEL ${ }^{a}: A_{\text {POD-NOAEL }}$} \\
\hline $\begin{array}{l}\text { Continuous end-point, } \\
\text { chronic/subchronic study }\end{array}$ & $1 / 3$ & 4.7 & $(0.07,1.6)$ & $\begin{array}{l}\text { Ratio of NOAEL to } B M D_{05} \\
(5 \% \text { relative change })\end{array}$ \\
\hline $\begin{array}{l}\text { Continuous end-point, } \\
\text { developmental study }\end{array}$ & $1 / 3$ & 7.0 & $(0.05,2.3)$ & $\begin{array}{l}\text { Ratio of NOAEL to } B M D_{05} \\
(5 \% \text { relative change })\end{array}$ \\
\hline $\begin{array}{l}\text { Deterministic quantal } \\
\text { end-point }\end{array}$ & $2 / 9$ & 5 & $(0.04,1.1)$ & $\begin{array}{l}\text { Ratio of NOAEL to } \mathrm{ED}_{50} \\
\text { (50\% response) }\end{array}$ \\
\hline $\begin{array}{l}\text { Stochastic quantal } \\
\text { end-point }\end{array}$ & $2 / 3$ & 4.7 & $(0.14,3.2)$ & $\begin{array}{l}\text { Ratio of NOAEL to } \text { BMD }_{10} \\
\text { (10\% extra risk) }\end{array}$ \\
\hline \multicolumn{5}{|l|}{ Exposure duration: $\mathrm{AF}_{\mathrm{Dur}}$} \\
\hline Subchronic $\rightarrow$ Chronic & 2 & 4 & $(1 / 2,8)$ & - \\
\hline Subacute $\rightarrow$ Chronic & 5 & 8 & $(5 / 8,40)$ & - \\
\hline \multicolumn{5}{|c|}{ Interspecies body size adjustment: $\mathrm{AF}_{\text {Inter-BS }}$} \\
\hline Oral & $\left(\frac{\mathrm{bw}_{\text {human }}}{\mathrm{bw}_{\text {testspecies }}}\right)^{0.3}$ & $\left(\frac{b_{W_{\text {human }}}}{\mathrm{bW}_{\text {test species }}}\right)^{0.04}$ & $\left(\frac{\mathrm{bw}_{\text {hummn }}}{\mathrm{bw}_{\text {tess speciss }}}\right)^{(0.26,0.34)}$ & $\begin{array}{l}\text { Use case-specific body } \\
\text { weights }\end{array}$ \\
\hline Inhalation & $\begin{array}{l}\text { 1/RDDR or } \\
\text { 1/RGDR }\end{array}$ & 2 & $\begin{array}{l}(0.5,2) / \\
\text { RDDR or } \\
(0.5,2) / \\
\text { RGDR }\end{array}$ & $\begin{array}{l}\text { Use case-specific RDDR } \\
\text { (particle) or RGDR }{ }^{\text {b }} \text { (gas) }\end{array}$ \\
\hline \multicolumn{5}{|c|}{ Interspecies TK/TD differences: $\mathrm{AF}_{\text {Inter-TK/TD }}$} \\
\hline Oral & 1 & 3 & $(1 / 3,3)$ & $\begin{array}{l}\text { Given lack of alternative, } \\
\text { can also be used for } \\
\text { inhalation }\end{array}$ \\
\hline \multicolumn{5}{|c|}{ Intraspecies differences for incidence $I: A_{\text {Intra-I }}$} \\
\hline$I=5 \%$ & 3.4 & 2.8 & $(1.8,14)$ & $\log \left(G S D_{H}\right) P 50=0.32$ \\
\hline$I=1 \%$ & 5.7 & 4.3 & $(2.2,42)$ & and P95/P50 = 2.2 \\
\hline$I=0.1 \%$ & 10 & 7.0 & $(2.9,143)$ & \\
\hline
\end{tabular}

$\mathrm{BMD}_{\mathrm{x}}$ : benchmark dose for $x \%$ benchmark response; bw: body weight; $\mathrm{ED}_{50}$ : median effective dose; $\mathrm{GSD}_{\mathrm{H}}$ : geometric standard deviation for interindividual variability in the human equipotent dose distribution; NOAEL: no-observed-adverse-effect level; P05: 5th percentile; P50: 50th percentile; P95: 95th percentile; PoD: point of departure; RDDR: regional deposited dose ratio; RGDR: regional gas dose ratio; TK/TD: toxicokinetic/ toxicodynamic

a When using a NOAEL as the PoD, the uncertainty includes both the fact that the NOAEL is an approximation for the BMDL as well as the uncertainty in the underlying BMD (a ratio of 3 is assumed between the median estimate of the BMD and the BMDL).

b For gases, the RGDR is often assumed to be 1. 
Table 2. Description of the exposure scenarios assessed for nanoscale $\mathrm{CuO}$ used in wood coating paints and nanoscale $\mathrm{Cu}_{2}(\mathrm{OH})_{2} \mathrm{CO}_{3}$ used in timber preserving impregnations.

\begin{tabular}{|c|c|c|c|c|c|c|}
\hline Exposure scenario (ES) & LC stage & Target & $\begin{array}{l}\text { Exposure } \\
\text { route }\end{array}$ & $\begin{array}{l}\text { Exposure level } \\
\left(E X P_{i}\right)\end{array}$ & Additional information & Source \\
\hline \multirow{2}{*}{$\begin{array}{l}\text { ES1: Laboratory scale CuO } \\
\text { powder production, } \\
\text { handling and packing }\end{array}$} & \multirow[t]{2}{*}{ SYN } & Worker & Inhalation & negligible & $\begin{array}{l}\text { Breathing zone and far field respirable mass concentrations below the minimum detection limits of } 161 \\
\text { and } 26 \mu \mathrm{g} \mathrm{m}^{-3} \text {, respectively, assuming background concentration level is } 0 \mu \mathrm{g} \mathrm{m}^{-3} \text {. }\end{array}$ & \multirow[t]{2}{*}{ (Fonseca et al.) } \\
\hline & & Worker & Dermal & negligible & Surface contamination was not detected, and dermal and perioral exposure are negligible* & \\
\hline \multirow[t]{2}{*}{$\begin{array}{l}\text { ES2: Pouring CuO } \\
\text { nanoscale powder in the } \\
\text { wood coating matrix }\end{array}$} & \multirow[t]{2}{*}{ FOR } & Worker & Inhalation & $\begin{array}{l}\mathrm{NF} 26 \mu \mathrm{g} / \mathrm{m}^{3} \\
\text { and FF } 10 \\
\mu \mathrm{g} / \mathrm{m}^{3}\end{array}$ & $\begin{array}{l}\text { In case the fume cupboard was active the concentration was }<0.2 \mu \mathrm{g} / \mathrm{m}^{3} \text {. If the fume cupboard would } \\
\text { be switched off and pouring would be performed in a room the concentration would be in the NF } 26 \\
\mu \mathrm{g} / \mathrm{m}^{3} \text { and FF } 10 \mu \mathrm{g} / \mathrm{m}^{3} \text { i.e. } 130 \text { times higher than with the fume cupboard. }\end{array}$ & \multirow[t]{2}{*}{$\begin{array}{l}\text { SUN project } \\
\text { deliverable } 5.4\end{array}$} \\
\hline & & Worker & Dermal & negligible & Surface contamination: dermal and perioral exposure are negligible* & \\
\hline \multirow[t]{2}{*}{$\begin{array}{l}\text { ES3: Applying CuO wood } \\
\text { coating to the substrate }\end{array}$} & \multirow[t]{2}{*}{ USE } & Worker & Inhalation & negligible & $\begin{array}{l}\text { Since CuO wood preservative is highly viscous (viscosity N/A) it is applied by brush to the substrate. } \\
\text { Release of respirable }\left(\mathrm{PM}_{4.5}\right) \mathrm{CuO} \text { wood preservative droplets is assumed to be negligible during brush } \\
\text { painting. Thus, the inhalation exposure is negligible. }\end{array}$ & \multirow[t]{2}{*}{ (ECHA 2016) } \\
\hline & & Worker & Dermal & negligible & Surface contamination: dermal and perioral exposure are negligible* & \\
\hline \multirow{4}{*}{$\begin{array}{l}\text { ES4: Sanding, cutting, } \\
\text { drilling and sawing wood } \\
\text { treated with CuO } \\
\text { preservative }\end{array}$} & \multirow[b]{2}{*}{ USE } & $\begin{array}{l}\text { Worker, } \\
\text { Consumer }\end{array}$ & Inhalation & $93 \mu \mathrm{g} / \mathrm{m}^{3}$ & Modelled $\mathrm{NF} \mathrm{CuO}_{2}$ concentration during continuous outdoor sanding. & $\begin{array}{l}\text { SUN project } \\
\text { deliverable } 5.4\end{array}$ \\
\hline & & $\begin{array}{l}\text { Worker, } \\
\text { Consumer }\end{array}$ & $\begin{array}{l}\text { Dermal, } \\
\text { Perioral }\end{array}$ & $\begin{array}{l}\text { Dermal: } \\
\text { negligible } \\
\text { Perioral: } 6,11 \mathrm{E}- \\
06 \quad \text { (SD 2.29E- } \\
06) \mathrm{mg} / \mathrm{kg} / \mathrm{day}\end{array}$ & $\begin{array}{l}\text { Surface contamination: dermal exposure is negligible, while perioral exposure has been assessed for } \\
\text { consumers based on the IEAT model and considering an average of } 6,3 \text { hand-to-mouth (oral or } \\
\text { perioral) contacts per day. }\end{array}$ & $\begin{array}{l}\text { SUN project } \\
\text { deliverable } 5.4 \text {, } \\
\text { (Gorman Ng et al. } \\
\text { 2016) }\end{array}$ \\
\hline & \multirow{2}{*}{ EOL } & Worker & Inhalation & negligible & \multirow{2}{*}{ The percentage of treated wood in the waste is very low, thus reducing the emission of CuO. } & \multirow{2}{*}{$\begin{array}{l}\text { (Heggelund et al. } \\
\text { 2016) }\end{array}$} \\
\hline & & Worker & Dermal & negligible & & \\
\hline $\begin{array}{l}\text { ES5: Consumers transfer } \\
\text { to skin from surfaces by } \\
\text { rubbing }\end{array}$ & USE & Consumer & Dermal & negligible & The wiping test performed in the SUN project indicated insignificant transfer to the skin. & $\begin{array}{l}\text { (Mackevica et al. } \\
\text { In preparation) }\end{array}$ \\
\hline \multirow{2}{*}{$\begin{array}{l}\mathrm{ES6}: \mathrm{Cu}_{2}(\mathrm{OH})_{2} \mathrm{CO}_{3} \text { powder } \\
\text { production, handling and } \\
\text { packing }\end{array}$} & \multirow{2}{*}{ SYN } & Worker & Inhalation & negligible & $\begin{array}{l}\text { In this study, we assume that the occupational exposure levels during } \mathrm{Cu}_{2}(\mathrm{OH})_{2} \mathrm{CO}_{3} \text { production, } \\
\text { handling and packaging are, like for CuO, below the detection limits, which were } 161 \mu \mathrm{g} \mathrm{m}^{-3}, 70 \text {, and } \\
200 \mu \mathrm{g} \mathrm{m}^{-3} \text {, respectively, when assuming background concentration level is } 0 \mu \mathrm{g} \mathrm{m}^{-3} \text {. }\end{array}$ & \multirow{2}{*}{ (Fonseca et al.) } \\
\hline & & Worker & Dermal & negligible & $\begin{array}{l}\text { Surface contamination: dermal and perioral exposure are negligible. According to the latest skin } \\
\text { penetration tests performed in SUN, dermal exposure is not relevant since the penetration rate is } \\
\text { negligible for nanomaterials }\end{array}$ & \\
\hline \multirow{2}{*}{$\begin{array}{l}\text { ES7: Milling of } \\
\mathrm{Cu}_{2}(\mathrm{OH})_{2} \mathrm{CO}_{3} \text { slurry for the } \\
\text { impregnation stock } \\
\text { solution }\end{array}$} & \multirow{2}{*}{ FOR } & Worker & Inhalation & negligible & $\begin{array}{l}\text { We assume that for the formulation phase, no inhalation exposure will occur due to negligible } \\
\text { emissions to the air (SUN deliverable } 2.3 \text { ) }\end{array}$ & \multirow{2}{*}{$\begin{array}{l}\text { SUN project } \\
\text { deliverable } 2.3\end{array}$} \\
\hline & & Worker & Dermal & negligible & Surface contamination: dermal exposure is negligible since emissions are negligible & \\
\hline \multirow{2}{*}{$\begin{array}{l}\text { ES8: Workers } \\
\text { impregnating wood in an } \\
\text { industrial setting }\end{array}$} & \multirow[t]{2}{*}{ USE } & Worker & Inhalation & negligible & $\begin{array}{l}\text { For the vacuum pressure treatment process in industrial scenario, the emissions to air are limited. So, } \\
\text { no relevant exposure scenarios are assessed }\end{array}$ & \multirow[t]{2}{*}{ (US EPA 1995) } \\
\hline & & Worker & Dermal & negligible & Surface contamination: dermal and perioral exposure are negligible* & \\
\hline \multirow{2}{*}{$\begin{array}{l}\text { ES9: Workers constructing } \\
\text { garden fences, decking, } \\
\text { cladding, playgrounds, } \\
\text { vegetable gardens using } \\
\text { the treated wood }\end{array}$} & \multirow[b]{2}{*}{ USE } & Worker & Inhalation & negligible & For waterborne preservatives, very low emissions to air & \multirow[b]{2}{*}{ (US EPA 1995) } \\
\hline & & Worker & Dermal & negligible & $\begin{array}{l}\text { Surface contamination: dermal and perioral exposure are negligible. According to the latest skin } \\
\text { penetration tests performed in SUN, dermal exposure is not relevant since the penetration rate is } \\
\text { negligible for nanomaterials }\end{array}$ & \\
\hline \multirow[b]{2}{*}{$\begin{array}{l}\text { ES10: Consumer transfer } \\
\text { to skin from surfaces by } \\
\text { rubbing }\end{array}$} & \multirow[b]{2}{*}{ USE } & Consumer & Inhalation & negligible & Inhalation exposure is assumed negligible & \multirow[b]{2}{*}{$\begin{array}{l}\text { (Mackevica et al. } \\
\text { In preparation) }\end{array}$} \\
\hline & & Consumer & Dermal & negligible & $\begin{array}{l}\text { Surface contamination: dermal and perioral exposure are negligible. According to the latest skin } \\
\text { penetration tests performed in SUN, dermal exposure is not relevant since the penetration rate is } \\
\text { negligible for nanomaterials }\end{array}$ & \\
\hline $\begin{array}{l}\text { ES11: Children exposed } \\
\text { directly to the treated } \\
\text { wood by skin contact, }\end{array}$ & USE & Consumer & Oral & $\begin{array}{l}0.07 \text { (SD 0.03) } \\
\mathrm{mg} / \mathrm{kg} / \mathrm{d}\end{array}$ & $\begin{array}{l}\text { Assuming an average weekly exposure of } 1.11 \mathrm{mg} / \text { day, corresponding to three visits to the playground } \\
\text { and dividing by the distribution of weights of children aged 8-36 months. }\end{array}$ & $\begin{array}{l}\text { (Platten et al. } \\
\text { 2014) }\end{array}$ \\
\hline
\end{tabular}




\begin{tabular}{|c|c|c|c|c|c|c|}
\hline $\begin{array}{l}\text { transfer of copper to the } \\
\text { month and related } \\
\text { ingestion }\end{array}$ & & & & & & \\
\hline \multirow{2}{*}{$\begin{array}{l}\text { ES12: Sanding, cutting, } \\
\text { drilling and sawing wood } \\
\text { treated with } \mathrm{Cu}_{2}(\mathrm{OH})_{2} \mathrm{CO}_{3} \\
\text { preservative }\end{array}$} & \multirow[b]{2}{*}{ EOL } & Worker & Inhalation & negligible & The percentage of treated wood in the waste is very low, thus reducing the emission of $\mathrm{Cu}_{2}(\mathrm{OH})_{2} \mathrm{CO}_{3}$. & \multirow[b]{2}{*}{$\begin{array}{l}\text { (Heggelund et al. } \\
\text { 2016) }\end{array}$} \\
\hline & & Worker & Dermal & negligible & Dermal deposition was considered negligible as the workers wear gloves. & \\
\hline \multirow{2}{*}{$\begin{array}{l}\text { ES13: Leaching during } \\
\text { contact with water and } \\
\text { related potential human } \\
\text { exposure (appl. to both } \\
\left.\mathrm{CuO} \text { and } \mathrm{Cu}_{2}(\mathrm{OH})_{2} \mathrm{CO}_{3}\right)\end{array}$} & USE & Consumer & Oral & negligible & $\begin{array}{l}\text { Leaching experiments performed in SUN showed that the released copper was solely in ionic form. } \\
\mathrm{Platten} \text { et al. (2014) showed that mostly ionic copper }(>\sim 95 \%) \text { is released from the wood treated with } \\
\mathrm{Cu}_{2}(\mathrm{OH})_{2} \mathrm{CO}_{3} \text { and that the particulate copper that was released is attached to cellulose and is therefore } \\
\text { not free in the solution. }\end{array}$ & $\begin{array}{l}\text { (Pantano et al. } \\
\text { 2018),(Platten et } \\
\text { al. 2014) }\end{array}$ \\
\hline & EOL & Public & Oral & negligible & $\begin{array}{l}\text { The percentage of treated wood in the landfilled waste is very low. Release from landfills is negligible in } \\
\text { general. }\end{array}$ & $\begin{array}{l}\text { (Heggelund et al. } \\
\text { 2016) }\end{array}$ \\
\hline
\end{tabular}


Table 3. Summary of exposure distributions $\left(\mathrm{EXP}_{\mathrm{i}}\right)$ for each scenario i.

\begin{tabular}{|c|c|c|c|c|c|c|c|c|}
\hline & ES1 & $\begin{array}{c}\text { ES2 } \\
\text { Inhalation }\end{array}$ & $\begin{array}{c}\text { ES2 } \\
\text { Dermal }\end{array}$ & ES3 & $\begin{array}{c}\text { ES4 } \\
\text { Inhalation } \\
\text { (Consumer } \\
\text { and Worker) }\end{array}$ & $\begin{array}{c}\text { ES4 } \\
\text { Perioral } \\
\text { (Consumer } \\
\text { and Worker) }\end{array}$ & $\begin{array}{l}\text { ES4 } \\
\text { End of } \\
\text { Life }\end{array}$ & ES5 \\
\hline $5 \%$ & \multirow{6}{*}{ Negligible } & $1,30 \mathrm{E}-02$ & \multirow{6}{*}{ Negligible } & \multirow{6}{*}{ Negligible } & $1,60 \mathrm{E}-01$ & $2,35 \mathrm{E}-06$ & \multirow{6}{*}{ Negligible } & \multirow{6}{*}{ Negligible } \\
\hline $95 \%$ & & $3,90 \mathrm{E}-02$ & & & $4,80 \mathrm{E}-01$ & $9,87 \mathrm{E}-06$ & & \\
\hline $50 \%$ (Median) & & $2,60 \mathrm{E}-02$ & & & $3,20 \mathrm{E}-01$ & $6,11 \mathrm{E}-06$ & & \\
\hline Mean & & $2,60 \mathrm{E}-02$ & & & $3,20 \mathrm{E}-01$ & $6,11 \mathrm{E}-06$ & & \\
\hline Mode & & $2,60 \mathrm{E}-02$ & & & $3,20 \mathrm{E}-01$ & $6,11 \mathrm{E}-06$ & & \\
\hline \multirow[t]{2}{*}{ SD } & & $7,90 \mathrm{E}-03$ & & & 9,73E-02 & $2,29 \mathrm{E}-06$ & & \\
\hline & ES6 & ES7 & ES8 & ES9 & ES10 & ES11 & ES12 & ES13 \\
\hline $5 \%$ & \multirow{6}{*}{ Negligible } & \multirow{6}{*}{ Negligible } & \multirow{6}{*}{ Negligible } & \multirow{6}{*}{ Negligible } & \multirow{6}{*}{ Negligible } & $3,23 \mathrm{E}-02$ & \multirow{6}{*}{ Negligible } & \multirow{6}{*}{ Negligible } \\
\hline 95\% & & & & & & $1,18 \mathrm{E}-01$ & & \\
\hline 50\% (Median) & & & & & & $6,80 \mathrm{E}-02$ & & \\
\hline Mean & & & & & & $7,06 \mathrm{E}-02$ & & \\
\hline Mode & & & & & & $6,30 \mathrm{E}-02$ & & \\
\hline SD & & & & & & $2,63 \mathrm{E}-02$ & & \\
\hline
\end{tabular}


Table 4. APROBA input data and output results.

\begin{tabular}{|c|c|c|c|c|c|}
\hline & Notes & $\begin{array}{c}\text { Unit of } \\
\text { measure }\end{array}$ & CuO Inhalation & CuO Ingestion & $\begin{array}{l}\mathrm{Cu}_{2}(\mathrm{OH})_{2} \mathrm{CO}_{3} \\
\text { Ingestion }\end{array}$ \\
\hline \multicolumn{6}{|c|}{ Inputs to APROBA } \\
\hline & & & $\begin{array}{c}\text { CuO } \\
\text { Inhalation }\end{array}$ & $\begin{array}{c}\text { CuO } \\
\text { Ingestion }\end{array}$ & $\begin{array}{l}\mathrm{Cu}_{2}(\mathrm{OH})_{2} \mathrm{CO}_{3} \\
\text { Ingestion }\end{array}$ \\
\hline Data type & & & Continuous & Continuous & Continuous \\
\hline Target BMR & & $\%$ & 100 & 5 & 5 \\
\hline PoD type & & & BMDL & NOAEL & NOAEL \\
\hline PoD unit of measure & & & $\mathrm{mg} / \mathrm{m} 3$ & $\mathrm{mg} / \mathrm{kg}$ bw/day & $\mathrm{mg} / \mathrm{kg}$ bw/day \\
\hline PoD value & & & 0,16 & 170,67 & 42,67 \\
\hline $\begin{array}{l}\text { BMDU (in case of using } \\
\text { the BMD approach) }\end{array}$ & & & 0,29 & --- & --- \\
\hline $\begin{array}{l}\text { Reference to support the } \\
\text { PoD selection }\end{array}$ & & & Gosens et al. (2016) & $\begin{array}{l}\text { De Jong et al } \\
\text { (submitted) }\end{array}$ & $\begin{array}{l}\text { De Jong et al } \\
\text { (submitted) }\end{array}$ \\
\hline $\begin{array}{l}\text { Factor used to correct PoD } \\
\text { to consider differences in } \\
\text { human and experimental } \\
\text { exposure conditions }\end{array}$ & \multirow[t]{2}{*}{$\begin{array}{l}\text { Workers are assumed to be exposed } 8 \\
\text { hours per day. This correction factor } \\
\text { applies in case of inhalation studies. }\end{array}$} & & 0,375 & n.a. & n.a. \\
\hline Exposure conditions & & h/day & 3 & n.a. & n.a. \\
\hline $\begin{array}{l}\text { Factor used to correct PoD } \\
\text { for differences in } \\
\text { respiratory volumes } \\
\text { between experimental } \\
\text { animals (at rest) and } \\
\text { humans (light activity). }\end{array}$ & $\begin{array}{l}\text { This correction factor applies in case } \\
\text { of inhalation studies. }\end{array}$ & & 0,67 & n.a. & n.a. \\
\hline $\begin{array}{l}\text { Corrected PoD value } \\
\text { (BMDL) }\end{array}$ & \multirow{2}{*}{$\begin{array}{l}\text { PoD (BMDL) and BMDU values } \\
\text { corrected multiplying original values } \\
\text { by the correction factors, in case of } \\
\text { inhalation studies. }\end{array}$} & & 0,040 & --- & --- \\
\hline $\begin{array}{l}\text { Corrected BMDU (in case } \\
\text { of using the BMD } \\
\text { approach) }\end{array}$ & & & 0,073 & --- & --- \\
\hline Data route & & & Inhalation & Oral & Oral \\
\hline Study type & & & Subacute & Subacute & Subacute \\
\hline Test species & & & Rat & Rat & Rat \\
\hline Species weight (average) & & $\mathrm{kg}$ & 0,332 & 0,228 & 0,366 \\
\hline Human weight & & $\mathrm{kg}$ & 70 & 70 & 10 \\
\hline $\begin{array}{l}\text { Population Incidence Goal } \\
\text { (I) }\end{array}$ & & $\%$ & $5 \%$ & $5 \%$ & $1 \%$ \\
\hline $\begin{array}{l}\text { Probabilistic Coverage } \\
\text { Goal }\end{array}$ & & $\%$ & $95 \%$ & $95 \%$ & $95 \%$ \\
\hline Overall deterministic UF & & n.a. & 100 & 100 & 100 \\
\hline \multicolumn{6}{|c|}{ Outputs from APROBA } \\
\hline NOAEL to BMD (LCL) & \multirow{2}{*}{$\begin{array}{c}\text { Uncertainty in transforming a NOAEL } \\
\text { to BMD }\end{array}$} & n.a. & 1 & 0,07 & 0,07 \\
\hline NOAEL to BMD (UCL) & & n.a. & 1 & 1,57 & 1,57 \\
\hline Interspecies scaling (LCL) & \multirow{2}{*}{$\begin{array}{c}\text { This aspect addresses the interspecies } \\
\text { adjustment to take into account } \\
\text { differences in body size (e.g. } \\
\text { allometric scaling). }\end{array}$} & n.a. & 1 & 4,43 & 2,36 \\
\hline Interspecies scaling (UCL) & & n.a. & 1 & 7,01 & 3,08 \\
\hline Interspecies TK/TD (LCL) & \multirow{2}{*}{$\begin{array}{l}\text { This aspect addresses remaining } \\
\text { interspecies TK and TD (toxicokinetics } \\
\text { and toxicodynamic differences) } \\
\text { differences after accounting for body } \\
\text { size differences. }\end{array}$} & n.a. & 0,333 & 0,333 & 0,333 \\
\hline Interspecies TK/TD (LCL) & & n.a. & 3 & 3 & 3 \\
\hline $\begin{array}{l}\text { Duration Extrapolation } \\
\text { (LCL) }\end{array}$ & \multirow{2}{*}{$\begin{array}{l}\text { This aspect addresses uncertainty in } \\
\text { using a less-than-chronic study (as } \\
\text { specified in "Study type" previously) to }\end{array}$} & n.a. & 0,625 & 0,625 & 0,625 \\
\hline Duration Extrapolation & & n.a. & 40 & 40 & 40 \\
\hline
\end{tabular}




\begin{tabular}{|c|c|c|c|c|c|}
\hline (UCL) & estimate a chronic PoD. & & & & \\
\hline Intraspecies (LCL) & \multirow{2}{*}{$\begin{array}{l}\text { This aspect addresses the uncertainty } \\
\text { in the amount of human variability in } \\
\text { sensitivity. It depends directly on the } \\
\text { "population incidence goal" entered } \\
\text { previously }\end{array}$} & n.a. & 1,77 & 1,77 & 2,24 \\
\hline Intraspecies (UCL) & & n.a. & 14,02 & 14,02 & 41,88 \\
\hline \multirow[t]{4}{*}{ Results } & $\begin{array}{l}\text { HD distribution (lognormally } \\
\text { distributed) }\end{array}$ & & $\begin{array}{l}\text { long term HD local } \\
\text { effects }\end{array}$ & $\begin{array}{c}\text { long term HD } \\
\text { systemic } \\
\text { effects }\end{array}$ & $\begin{array}{c}\text { long term HD } \\
\text { systemic } \\
\text { effects }\end{array}$ \\
\hline & Unit of measure & & $\mathrm{mg} / \mathrm{m} 3$ & $\begin{array}{c}\mathrm{mg} / \mathrm{kg} \text { body } \\
\text { weight per day }\end{array}$ & $\begin{array}{c}\mathrm{mg} / \mathrm{kg} \text { body } \\
\text { weight per day }\end{array}$ \\
\hline & LCL (P05) & & $1,63-04$ & $7,85 \mathrm{E}-02$ & 0,041 \\
\hline & UCL (P95) & & $2,88 \mathrm{E}-02$ & $4,55 \mathrm{E}+01$ & 23,5 \\
\hline
\end{tabular}

771 Table 5. Long-term HD log-normal probability distributions statistics for CuO (ingestion and inhalation routes) and

772 for $\mathrm{Cu}_{2}(\mathrm{OH})_{2} \mathrm{CO}_{3}$ (ingestion route).

\begin{tabular}{|l|c|c|c|}
\cline { 2 - 4 } \multicolumn{1}{c|}{} & $\begin{array}{c}\mathrm{CuO} \\
\text { Inhalation }\end{array}$ & $\begin{array}{c}\mathbf{C u O} \\
\text { Ingestion }\end{array}$ & $\begin{array}{c}\mathrm{Cu}_{2}(\mathrm{OH})_{2} \mathrm{CO}_{3} \\
\text { Ingestion }\end{array}$ \\
\hline $\mathbf{5 \%}$ & $1,63 \mathrm{E}-04$ & $1,81 \mathrm{E}-01$ & $4,09 \mathrm{E}-02$ \\
\hline $\mathbf{9 5 \%}$ & $2,88 \mathrm{E}-02$ & $7,44 \mathrm{E}+01$ & $2,35 \mathrm{E}+01$ \\
\hline $\mathbf{5 0 \%}$ (median) & $2,17 \mathrm{E}-03$ & $3,67 \mathrm{E}+00$ & $9,80 \mathrm{E}-01$ \\
\hline Mean & $7,48 \mathrm{E}-03$ & $1,96 \mathrm{E}+01$ & $6,33 \mathrm{E}+00$ \\
\hline $\mathbf{G M}$ & $2,17 \mathrm{E}-03$ & $3,67 \mathrm{E}+00$ & $9,80 \mathrm{E}-01$ \\
\hline SD factor & $4,82 \mathrm{E}+00$ & $6,23 \mathrm{E}+00$ & $6,90 \mathrm{E}+00$ \\
\hline
\end{tabular}

773

774 Table 6. Risk Characterisation Ratio (RCR) distributions of risk for all assessed exposure scenarios (ES). These

775 statistics are the result from over 10000 Monte Carlo simulations.

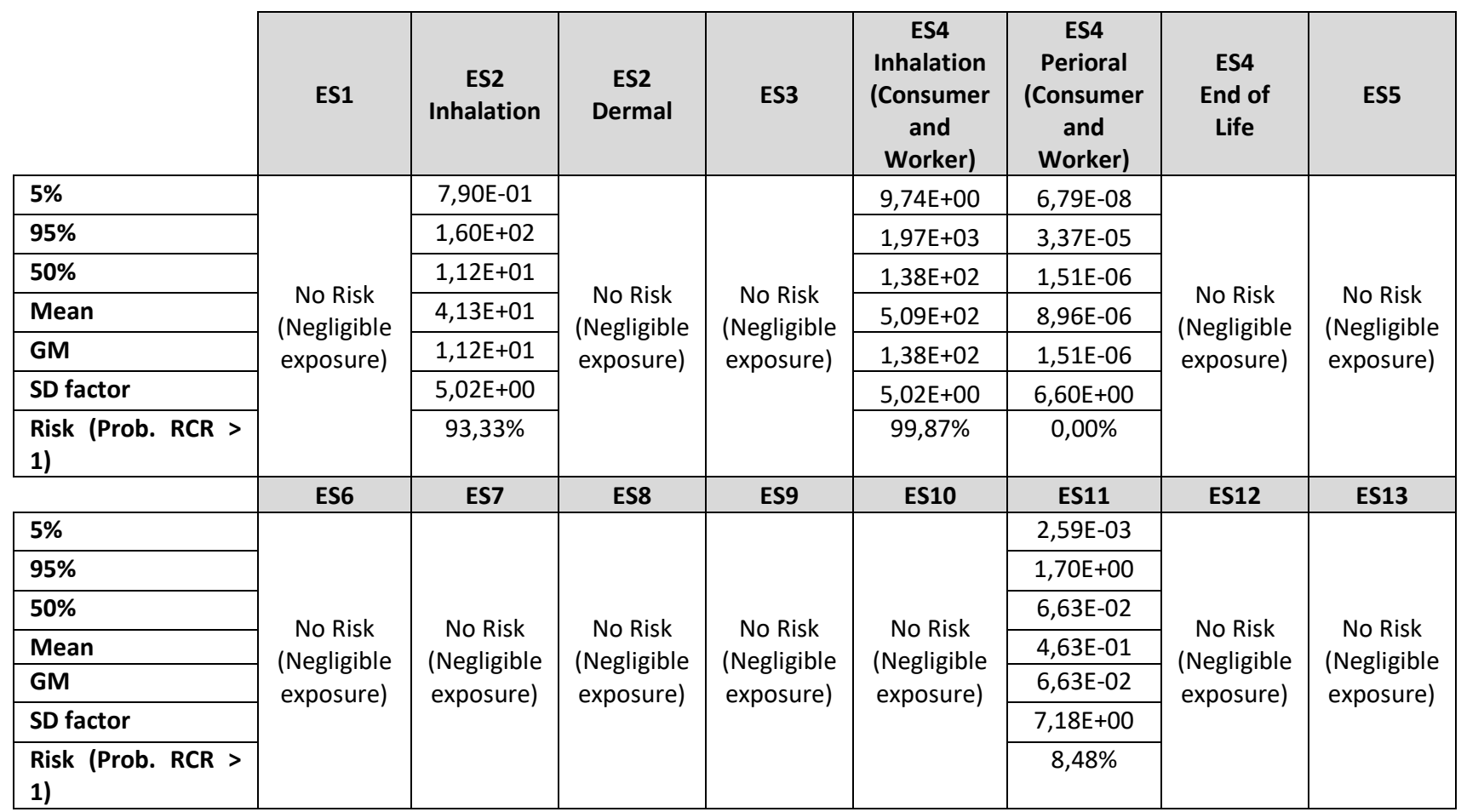


SUNDS Human Health Risk Assessment Module

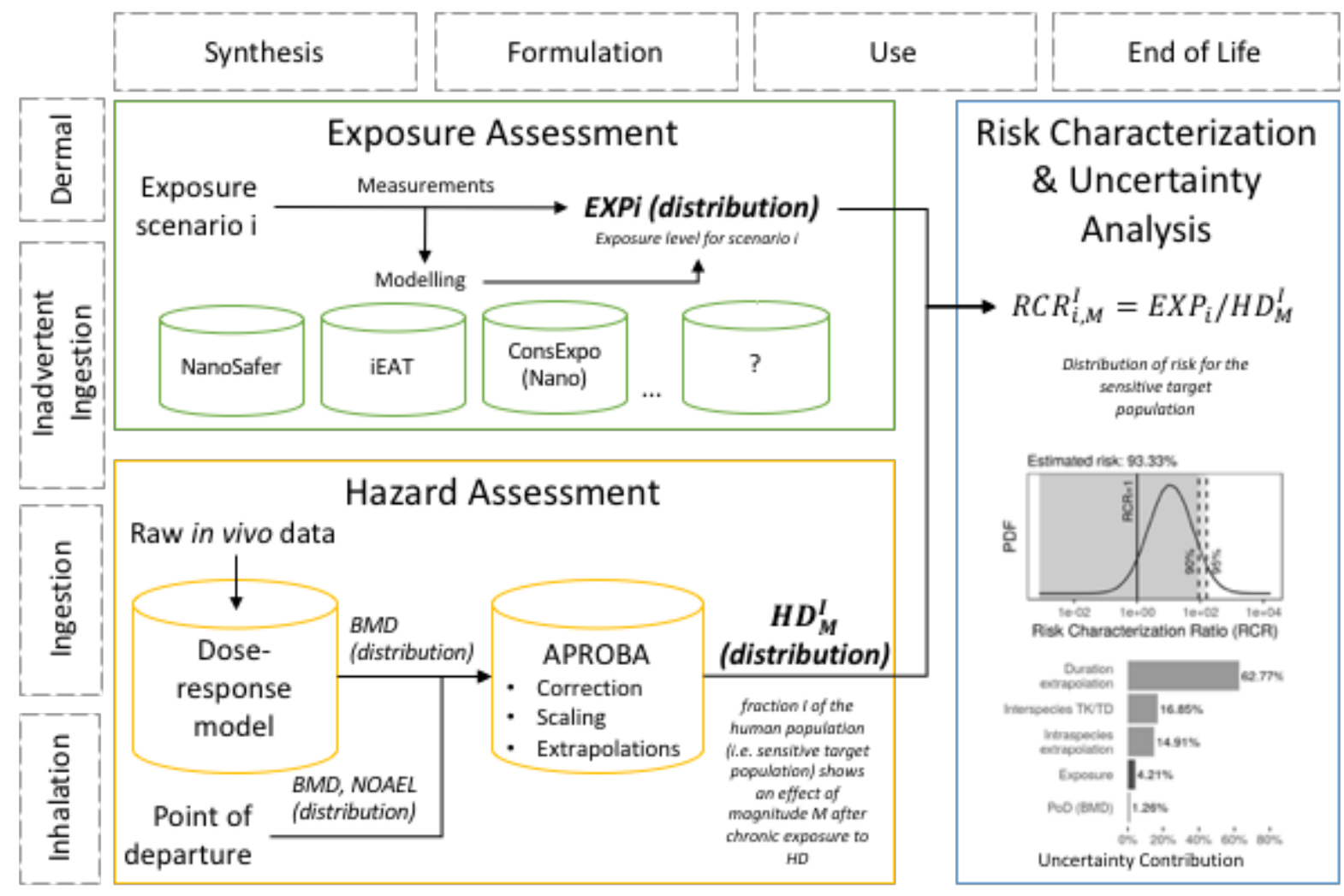

Figure 1. Structure, models, inputs and outputs of the human health risk assessment module of the SUN

781 Decision Support System (SUNDS). 
ES2 - Inhalation

Estimated risk: $93.33 \%$

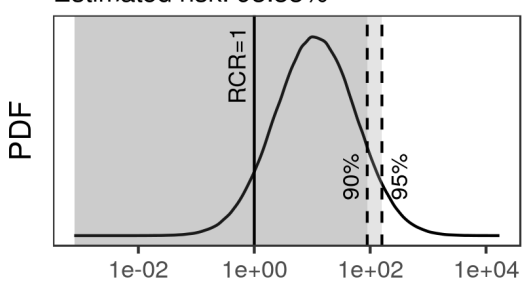

Risk Characterization Ratio (RCR)

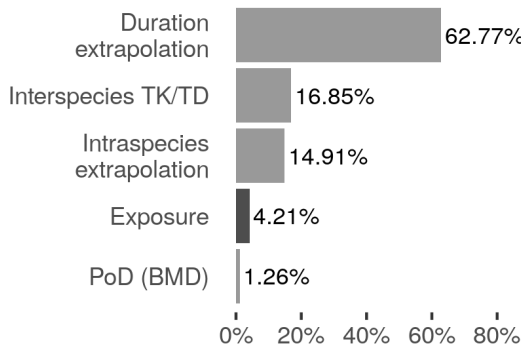

ES4 - Perioral (Consumer)

Estimated risk: $0 \%$

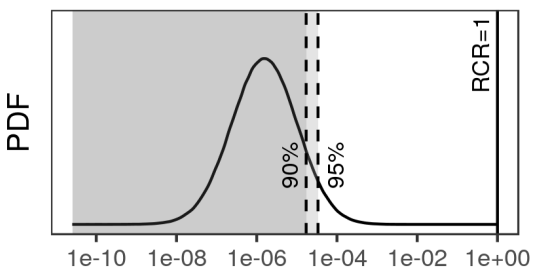

Risk Characterization Ratio (RCR)

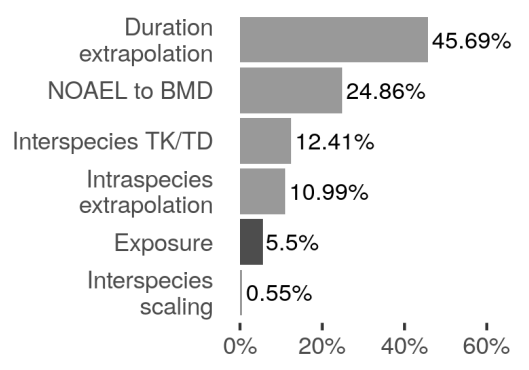

ES4 - Inhalation (Consumer)

Estimated risk: $99.87 \%$

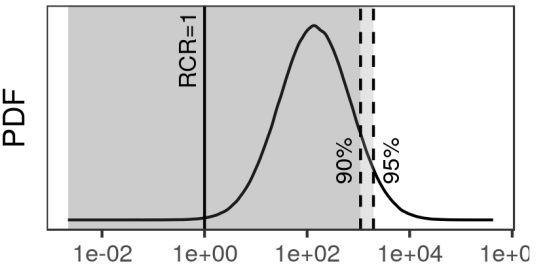

Risk Characterization Ratio (RCR)

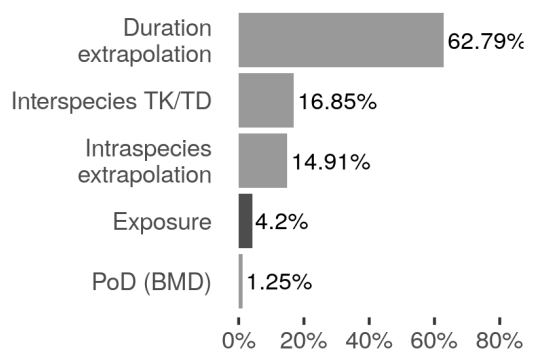

ES4 - Perioral (Worker)

Estimated risk: $0 \%$

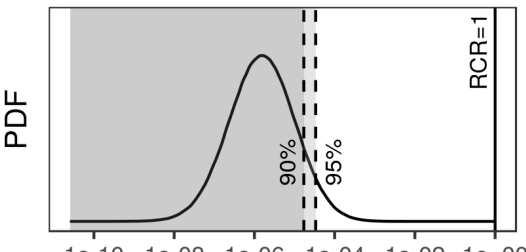

$\begin{array}{llllll}1 e-10 & 1 e-08 & 1 e-06 & 1 e-04 & 1 e-02 & 1 e+00\end{array}$ Risk Characterization Ratio (RCR)

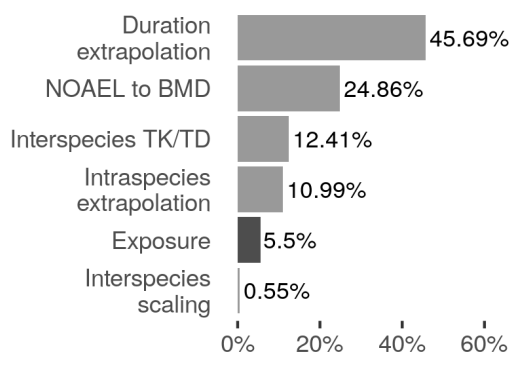

ES4 - Inhalation (Worker)

Estimated risk: $99.87 \%$

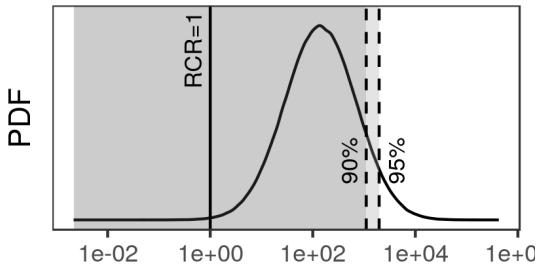

Risk Characterization Ratio (RCR)

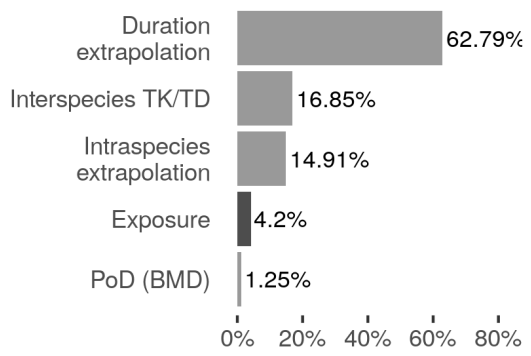

ES11 - Oral

Estimated risk: $8.48 \%$

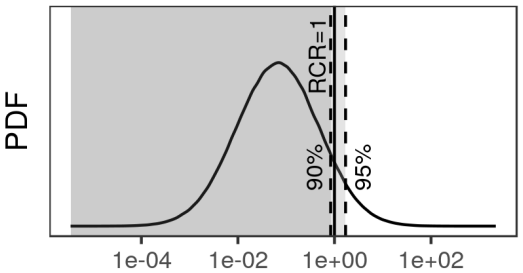

Risk Characterization Ratio (RCR)

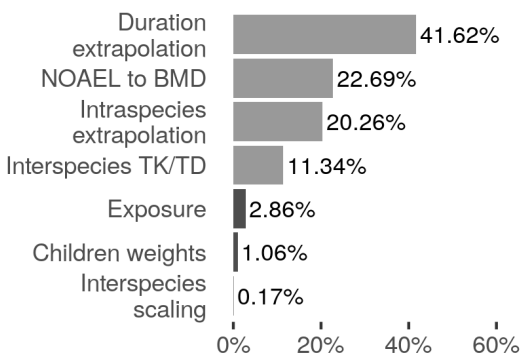

Figure 2. Risks along the lifecycles of the $\mathrm{CuO}$ and $\mathrm{Cu}_{2}(\mathrm{OH})_{2} \mathrm{CO}_{3}$ based products for all concerning exposure scenarios (ES). Contributions of the different sources of uncertainty to the total uncertainty, derived from over 10000 Monte Carlo simulations, are highlighted. 
796

797 